\title{
The Effect of Different Freezing Rates and Long-Term Storage Temperatures on the Stability of Sliced Peaches
}

\author{
Paul Dawson (D), ${ }^{1}$ Wesam Al-Jeddawi, ${ }^{1}$ and James Rieck ${ }^{2}$ \\ ${ }^{1}$ Department of Food, Nutrition and Packaging Sciences, Clemson University, USA \\ ${ }^{2}$ Department of Mathematical Sciences, Clemson University, Clemson, South Carolina 29634, USA \\ Correspondence should be addressed to Paul Dawson; pdawson@clemson.edu
}

Received 17 March 2020; Revised 20 October 2020; Accepted 24 October 2020; Published 19 November 2020

Academic Editor: Alejandro Castillo

Copyright (C) 2020 Paul Dawson et al. This is an open access article distributed under the Creative Commons Attribution License, which permits unrestricted use, distribution, and reproduction in any medium, provided the original work is properly cited.

\begin{abstract}
The purpose of this research was to determine if freezing rates and holding temperatures influence peach quality during short- and long-term frozen storage. Fresh peaches (Prunus persica) were purchased locally, sliced, dipped in 2\% ascorbic acid then drained, and packaged. The study was divided into two experiments, one to determine the effect of the freezing rate on peach quality and the second to determine the effect of frozen holding temperatures on peach quality. For the freezing rate experiment, freshly packaged peaches were placed in freezers at different temperatures $\left(-7^{\circ} \mathrm{C},-12^{\circ} \mathrm{C},-18^{\circ} \mathrm{C},-29^{\circ} \mathrm{C}\right.$, and $\left.-77^{\circ} \mathrm{C}\right)$ then removed for testing when the core temperature of the peaches reached the temperature of all freezer temperatures. The second experiment determined the longterm holding effect on quality using both fresh and prefrozen peaches held at $-7^{\circ} \mathrm{C},-12^{\circ} \mathrm{C},-18^{\circ} \mathrm{C},-29^{\circ} \mathrm{C}$, and $-77^{\circ} \mathrm{C}$ through 360 days Quality measurements included freeze thaw and weight loss, lightness, firmness, moisture content, ascorbic acid equivalent antioxidant capacity (AAEAC), hexanal detection using gas chromatography (GC), scanning electron microscopy (SEM), and sensory evaluation. During the freezing phase (experiment 1), peach weight loss and surface ice crystal pore size significantly decreased with increased freezing rates. Peaches held at $-77^{\circ} \mathrm{C}$ and $-29^{\circ} \mathrm{C}$ maintained overall quality to a greater degree than the higher holding temperatures. However, all samples enzymatically browned when thawed; therefore, frozen peaches may best if used in the frozen state or in applications where appearance is a critical factor. In general, fresh and prefrozen peaches were not acceptable by the sensory panelists after 270 days of frozen storage.
\end{abstract}

\section{Introduction}

Since fruits grow only in certain parts of the world under certain temperature and humidity conditions and seasonally, preservation is a key factor to avail these foods to humans out of season and in regions where these fruits do not grow well. Fruits contain approximately $90 \%$ water which begin to undergo higher rates of respiration once they are harvested, resulting in moisture loss, quality deterioration, and potential microbial spoilage [1]. Refrigeration slows down the respiration of fruits to increase shelf life [1]; however, fruits continue to degrade during refrigeration. Freezing offers a retention of nutrients and other quality attributes during long-term storage. Prior to freezing, peaches are pitted, peeled, and sliced. While freezing minimizes loss of nutrients and slows enzymatic browning, browning still occurs during freezing and thawing [2].
Freezing has been successfully employed for the longterm preservation of many foods by lowering temperature to $-18^{\circ} \mathrm{C}$ or below [3]. In fact, 6 to $8 \%$ of peaches produced are processed as frozen peaches [4]. While the holding temperature of frozen fruit is critical to retain quality, freezing rate can have an even more dramatic effect on fruit quality. Rapid freezing can prevent the loss of water from the plant cell through osmosis while slower freezing rates allow adequate time for water to migrate from the cell resulting in greater drip loss for slowly frozen fruits [2]. Because of the wall, damage during freezing, water does not return to the cells upon thawing but instead becomes drip loss [2]. Freezing fruits retard the physical, chemical, and biochemical reactions which induce phytochemical deterioration. Most of the liquid water is transformed into ice during freezing, which slows microbial, enzymatic, and lipid oxidation reactions [5]. Enzymatic 
reactions are a major concern in the deterioration of frozen fruits. Enzyme activity has been noted in foods stored at temperatures as low as $-73^{\circ} \mathrm{C}$ [6]. Color loses in frozen vegetables containing chlorophyll due to pheophytisation occurs when the magnesium found in the center of chlorophyll's porphyrin ring is lost and replaced with hydrogen [7]. This reaction is caused when $\mathrm{pH}$ decreases during frozen storage thus initiating the pheophytisation reaction [7]. Texture is another key quality factor in fresh fruit because it determines acceptability [8]. Slow freezing rates result in large ice crystals that cause fruit cell wall damage leading to an undesirable mushy texture in frozen fruits. After thawing, fruit will be softer due to cell damage and water migration from the fruit cell structure. Phytochemicals in high concentration in fruits include phenolic compounds such as flavonoids anthocyanins, flavanols, and phenolic acids [9]. Flavonoids are primarily found in the skin of fruit, which contribute to important quality aspects such as aroma and color [10]. Since phenolic compounds are antioxidants, they are subject to oxidation during storage and processing of foods [11]. Cold storage can help retain nutritional components, for example, plums held at $0^{\circ} \mathrm{C}$ and had lower rates of vitamin $\mathrm{C}$ degradation compared with those kept at $5^{\circ} \mathrm{C}$ and $12^{\circ} \mathrm{C}$ [12]. While extensive research has shown lower temperatures slow the degradation of nutrients and other chemical degradative reactions, the difference in the rate of degradation between temperatures used in commercial freezers may not be evident. More energy-efficient freezers may be possible if research indicates that quality loss is not significant when frozen fruit is stored at slightly higher freezer temperatures.

\section{Materials and Methods}

2.1. Sample Preparation. Peaches (Prunus persica) purchased locally were rinsed with tap water, dried with a paper towel, and then cut into 8 slices. The weight of each slice was approximately $12 \mathrm{~g}$ to $14 \mathrm{~g}$. The slices were dipped in $2 \%$ of L-ascorbic acid (Food Grade, Sigma Aldrich, Saint Louis, MO 63103, USA) for 2 minutes. The slices were then drained and packaged in Whirl Pak bags (Nasco, Sigma Aldrich, St. Louis, MO 63103, USA) then stored at $3.3 \pm 2^{\circ} \mathrm{C}$ for 2 hours. For the long-term storage study, prefrozen peach slices were obtained from a commercial supplier and held at $-20^{\circ} \mathrm{C}$ until use. Both prefrozen and fresh peaches were used in the long-term storage study. The size and weight of each frozen slice were approximately the same for prefrozen samples as the fresh peach slices ( $12 \mathrm{~g}$ to $14 \mathrm{~g}$ ).

For experiment 1 (short-term storage), peaches were placed into freezers having five different set temperatures $\left(-7^{\circ} \mathrm{C},-12^{\circ} \mathrm{C},-18^{\circ} \mathrm{C},-29^{\circ} \mathrm{C}\right.$, and $\left.-77^{\circ} \mathrm{C}\right)$ and then were removed for testing when core holding temperatures reached these set temperatures within each freezer. Since there were 5 endpoint temperatures for the $-77^{\circ} \mathrm{C}$ freezer, 4 for the $-29^{\circ} \mathrm{C}$ freezer, 3 for the $-18^{\circ} \mathrm{C}$ freezer, 2 for the $-12^{\circ} \mathrm{C}$, and 1 for the $-7^{\circ} \mathrm{C}$ freezer, this resulted in a total of 15 different treatments (Figure 1). For experiment 2 (long-term storage), fresh and prefrozen peach samples were stored randomly in freezers set at different temperatures $\left(-7^{\circ} \mathrm{C},-12^{\circ} \mathrm{C},-18^{\circ} \mathrm{C},-29^{\circ} \mathrm{C}\right.$, and $\left.-77^{\circ} \mathrm{C}\right)$ for 360 days (Figure 2). The 15 treatments resulted in different freezing times for each of the endpoint temperatures (Figure 3). Fresh peach samples were prepared as described for experiment 1 while prefrozen samples were obtained from a commercial source. The core temperature of one peach slice within each freezer was monitored throughout storage with a thermocouple, and the internal freezer temperature and humidity were recorded using a sensor. The quality attribute tests for the fresh and prefrozen peaches were conducted on days $0,30,90,180,270$, and 360. On day 0 , fresh and prefrozen samples were removed from each freezer set at $-7^{\circ} \mathrm{C},-12^{\circ} \mathrm{C},-18^{\circ} \mathrm{C},-29^{\circ} \mathrm{C}$, and $-77^{\circ} \mathrm{C}$ for testing. Two peach slices from each treatment were freeze-dried for the scanning electron microscopy (SEM) for ice crystal pore size analysis. Freeze loss and lightness $\left(L^{*}\right)$ tests were measured after freezing before thawing. Other tests were conducted after thawing in the refrigerator at $3.3 \pm 2{ }^{\circ} \mathrm{C}$ for 24 hours.

2.2. Freeze Loss. Percent freeze loss was determined by weighing (Mettler Toledo PB3002 scale, Langacher Greifensee, Switzerland) fresh and prefrozen samples before each peach sample was placed into their respective freezers and then again after freezing. The percent freeze loss was calculated based on this equation:
\%freeze loss $=($ weight before freezing - weight after freezing $)$ /weight before freezing $* 100$.

2.3. Thaw Loss. Percent thaw loss was determined by weighing (Mettler Toledo PB3002 scale, Langacher Greifensee, Switzerland) fresh and prefrozen samples after freezing and then again after thawing. The percent thaw loss was calculated based on this equation:

$$
\begin{aligned}
\% \text { thaw loss }= & (\text { weight after freezing }- \text { weight after thawing }) \\
& \text { / weight after freezing } * 100 .
\end{aligned}
$$

2.4. Weight Loss. Total percent weight loss was determined based summing the percent freeze loss and percent thaw loss. The percent weight loss was calculated based on this equation:

$$
\text { \%weight loss }=(\% \text { freeze loss }+\% \text { thaw loss }) \text {. }
$$

2.5. Color. Lightness $\left(L^{*}\right), a^{*}$, and $b^{*}$ were measured on raw and frozen peach samples using a Minolta Colorimeter with a DP-400 data processor and CM-400 Chroma Meter (Minolta, Colorado) as described by [13]. The color analysis for frozen peach treatments was performed directly after weighing. Plastic wrap was used to cover 

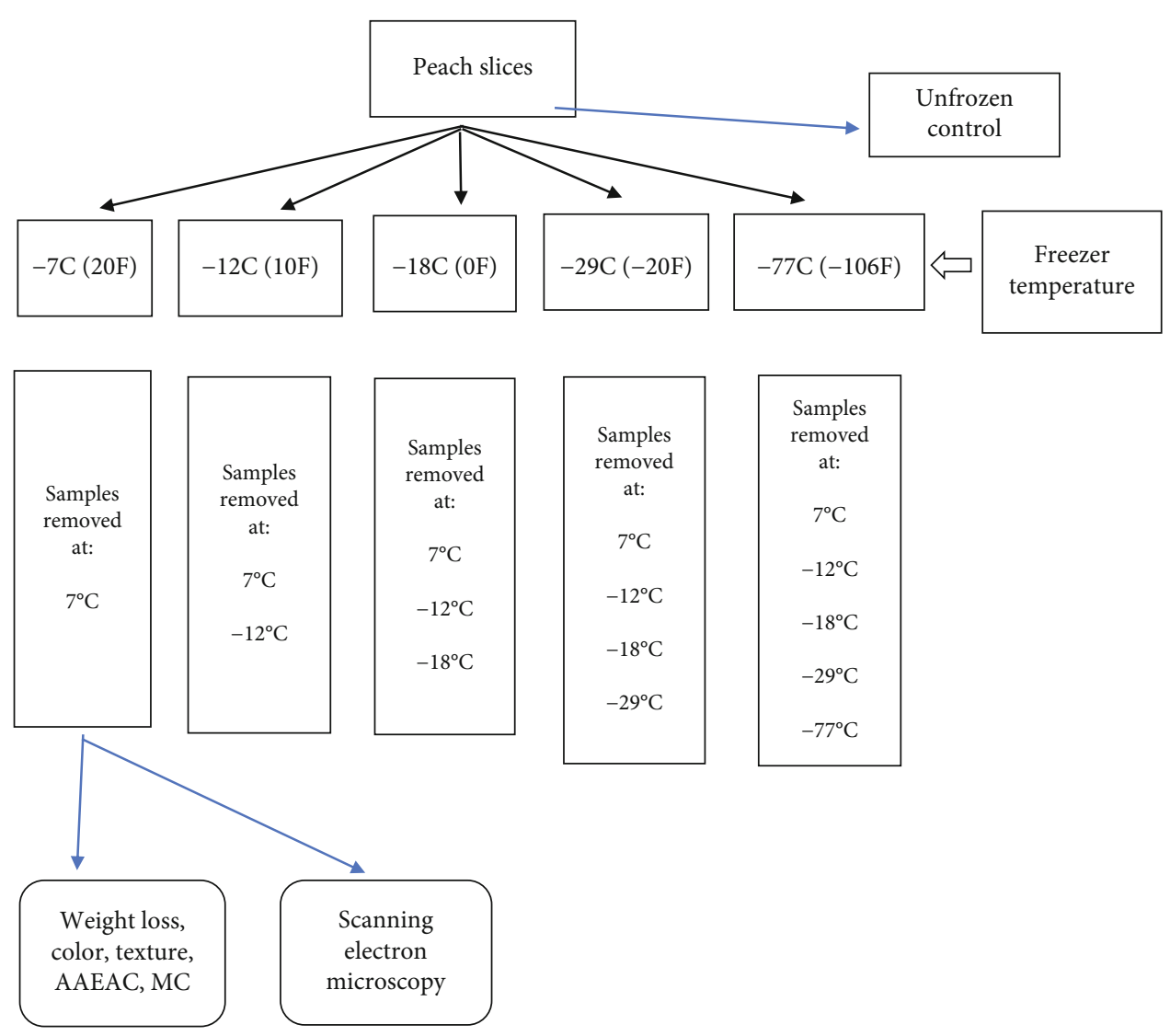

FIGURE 1: Flowchart for experiment 1 for short-term frozen storage effects on peach slice quality.

\begin{tabular}{|c|c|c|c|c|}
\hline $\begin{array}{c}\text { Fresh \& } \\
\text { prefrozen } \\
\text { stored at } \\
\text { freezer: }\left(-7^{\circ} \mathrm{C}\right)\end{array}$ & $\begin{array}{c}\text { Fresh \& } \\
\text { prefrozen } \\
\text { stored at } \\
\text { freezer: }\left(-12^{\circ} \mathrm{C}\right)\end{array}$ & $\begin{array}{c}\text { Fresh \& } \\
\text { prefrozen } \\
\text { stored at } \\
\text { freezer: }\left(-18^{\circ} \mathrm{C}\right)\end{array}$ & $\begin{array}{c}\text { Fresh \& } \\
\text { prefrozen } \\
\text { stored at } \\
\text { freezer: }\left(-29^{\circ} \mathrm{C}\right)\end{array}$ & $\begin{array}{c}\text { Fresh \& } \\
\text { prefrozen } \\
\text { stored at } \\
\text { freezer: }\left(-77^{\circ} \mathrm{C}\right)\end{array}$ \\
\hline \multicolumn{5}{|c|}{ Quality attribute tests were conducted in days $0,30,90,180,270$ and 360} \\
\hline \multicolumn{2}{|c|}{ Freeze loss } & \multicolumn{3}{|c|}{ Antioxidant capacity (AAEAC) } \\
\hline \multicolumn{2}{|c|}{ Thaw loss } & \multicolumn{3}{|c|}{ Pore numbers (SEM) } \\
\hline \multicolumn{2}{|c|}{ Weight loss } & \multicolumn{3}{|c|}{ Pore size (SEM) } \\
\hline \multicolumn{2}{|c|}{ Lightness } & \multicolumn{3}{|c|}{ Hexanal (GC) } \\
\hline \multicolumn{2}{|c|}{ Firmness } & \multicolumn{3}{|c|}{ Sensory evaluation } \\
\hline \multicolumn{2}{|c|}{ Moisture content } & & & \\
\hline
\end{tabular}

FIGURE 2: Flowchart for experiment 2 for long-term frozen storage effects on peach slice quality.

the peach treatments during color readings to protect the Chroma Meter. The influence of the plastic wrap on color was accounted for during calibration. Color was also measured on samples after freezing and after thawing.
2.6. Texture (Firmness). The firmness with and without the pericarp was determined based on the method described by [13]. A TA-XT Plus texture analyzer (Stable Micro-Systems Texture Technologies Corp, Scarsdale, New York, NY, 


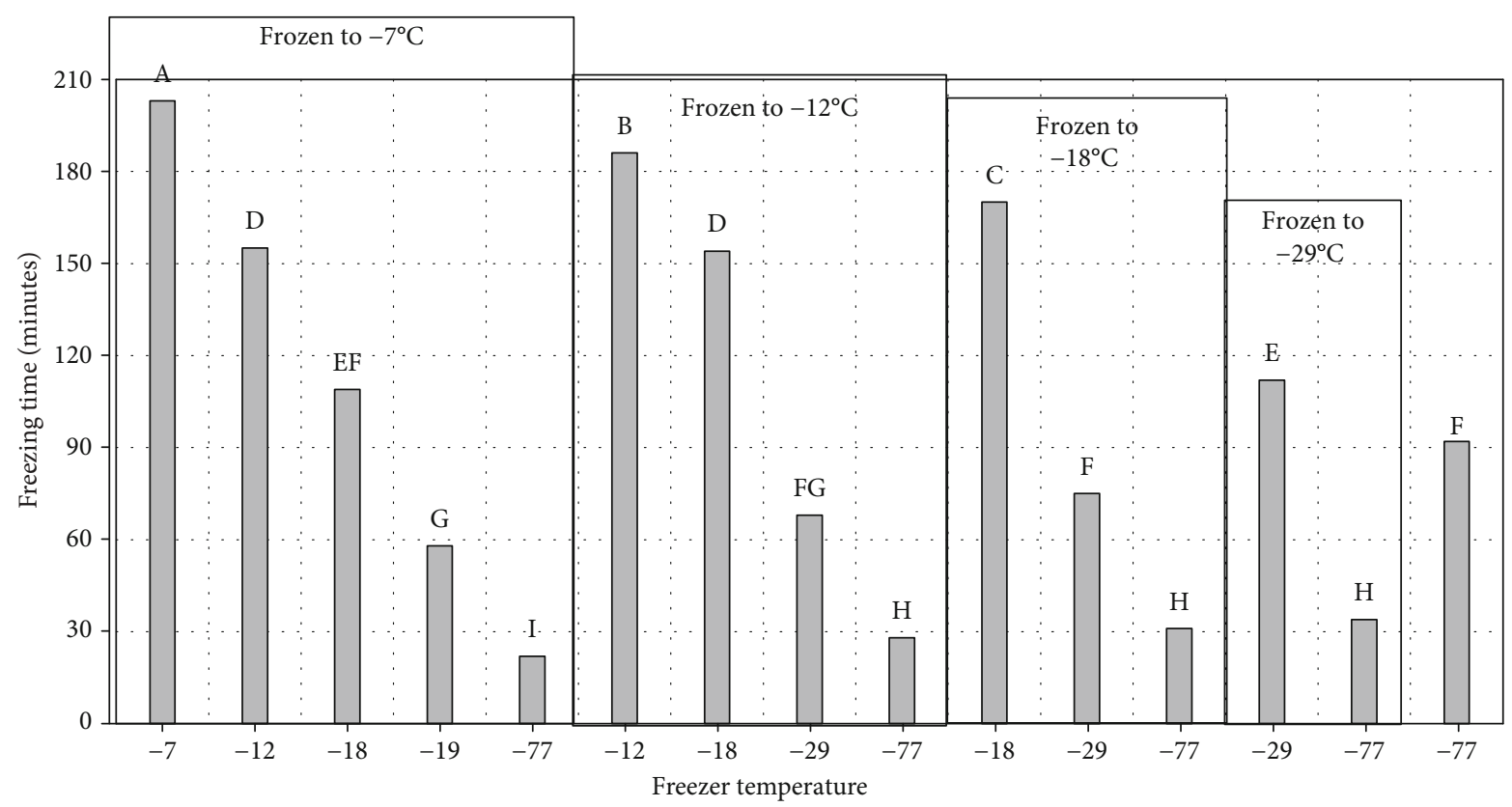

Figure 3: Freezing time for different freezer temperatures and endpoint core temperature. ${ }^{* \mathrm{a}-\mathrm{i}}$ Treatments with different letters are significantly different $(P \leq 0.05) . n=3$. Standard error $=5.9$.

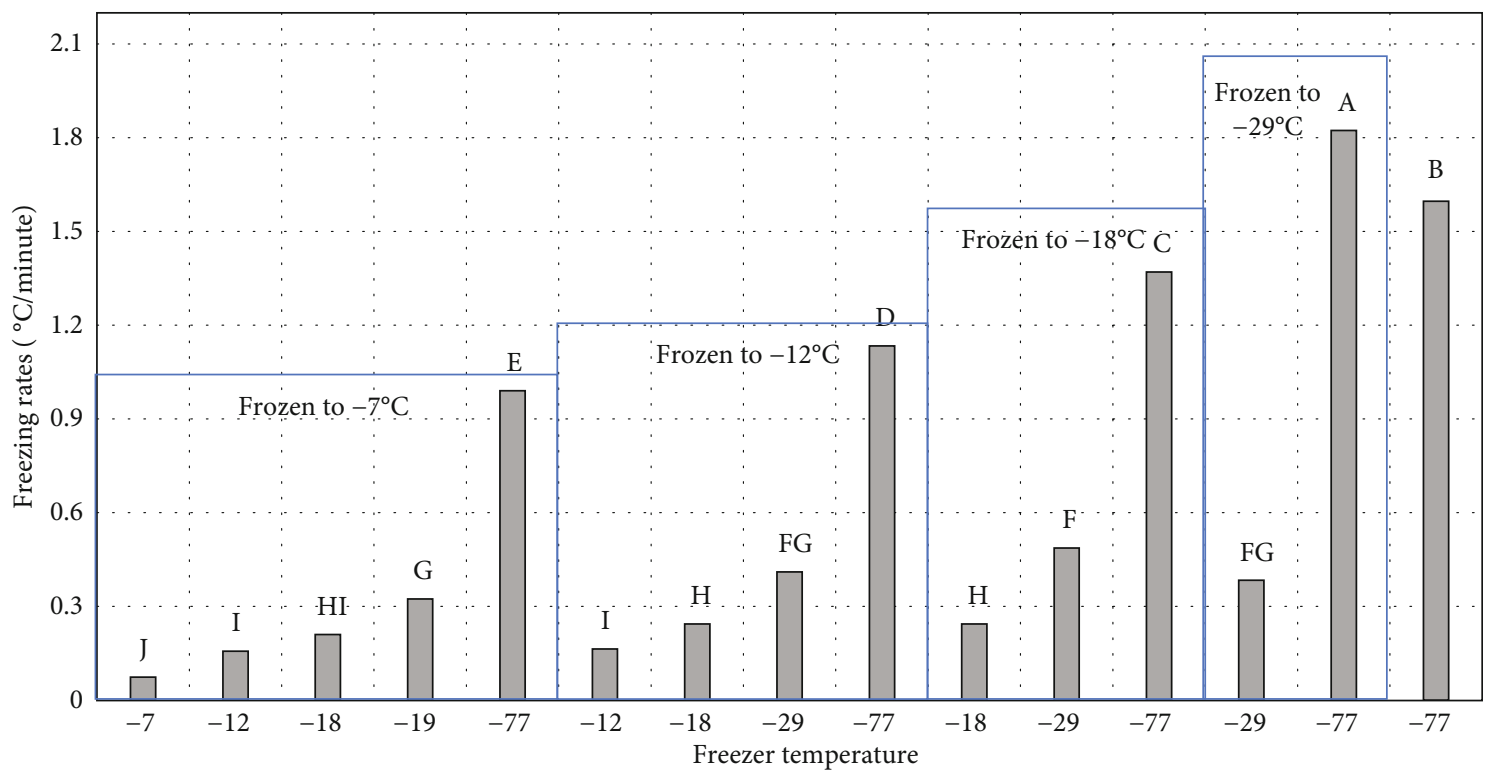

FiguRE 4: Freezing rates for treatments frozen (freezer temperature environment). ${ }^{* \mathrm{a}-\mathrm{j}}$ Treatments with different letters are significantly different $(P \leq 0.05) . n=3$. Standard error $=0.03$.

USA) was used for the analysis with a probe diameter of $8 \mathrm{~mm}$, a test depth of $5 \mathrm{~mm}$, and at a penetration rate of $1 \mathrm{~mm} \mathrm{~s}^{-1}$.

2.7. Freeze-Drying Process. Two slice samples (per replication) were used for ice crystal analysis by first freeze-drying (Labconco Lyph-lock 6 Freeze Dry System, Kansas City, Missouri) to remove moisture and stabilize ice crystal pores. Freeze drying was achieved under a condenser temperature range of $-44^{\circ} \mathrm{C}$ to $-48^{\circ} \mathrm{C}$ and a vacuum pressure range of 50 $\times 10^{-3}$ to $500 \times 10^{-3}$ millibars. Samples were removed from the freeze dryer after five days and stored in a $3.33^{\circ} \mathrm{C}\left(38^{\circ} \mathrm{F}\right)$ refrigerator overnight before microscopy analysis.

2.7.1. Scanning Electron Microscopy (SEM). The surface and core areas of the freeze-dried treatments were analyzed with a S-3400N Variable-Pressure SEM (VP-SEM) (Hitachi High-Technologies Corporation, Clarksburg, Maryland) 


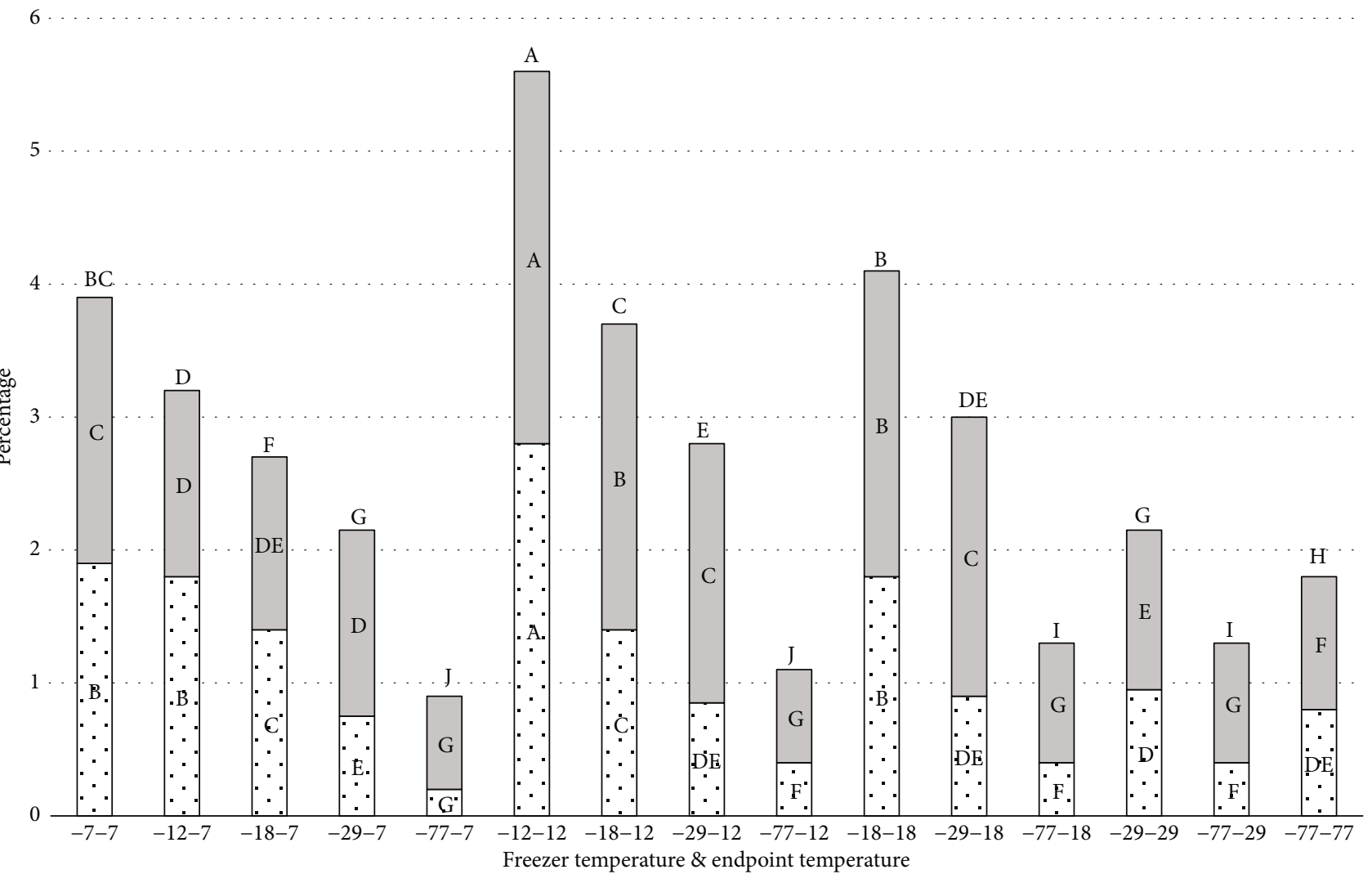

Freeze loss

$\square$ Thaw loss

Figure 5: Weight loss for frozen and thawed and combined loss for fresh peaches frozen at different rates and to different endpoint temperatures. $-7-7=$ freezer temperature is $-7^{\circ} \mathrm{C}$, and sample endpoint core temperature is $-7^{\circ} \mathrm{C} .-12-7=$ freezer temperature is $-12^{\circ} \mathrm{C}$, and sample endpoint core temperature is $-7^{\circ} \mathrm{C} .-18-7=$ freezer temperature is $-18^{\circ} \mathrm{C}$, and sample endpoint core temperature is $-7^{\circ} \mathrm{C}$. $-29-$ $7=$ freezer temperature is $-29^{\circ} \mathrm{C}$, and sample endpoint core temperature is $-7^{\circ} \mathrm{C}$. $-77-7=$ freezer temperature is $-77^{\circ} \mathrm{C}$, and sample endpoint core temperature is $-7^{\circ} \mathrm{C}$. $-12-12=$ freezer temperature is $-12^{\circ} \mathrm{C}$, and sample endpoint core temperature is $-12^{\circ} \mathrm{C}$. $-18-12=$ freezer temperature is $-18^{\circ} \mathrm{C}$, and sample endpoint core temperature is $-12^{\circ} \mathrm{C}$. $-29-12=$ freezer temperature is $-29^{\circ} \mathrm{C}$, and sample endpoint core temperature is $-12^{\circ} \mathrm{C} .-77-12=$ freezer temperature is $-77^{\circ} \mathrm{C}$, and sample endpoint core temperature is $-12^{\circ} \mathrm{C} .-18-18=$ freezer temperature is $-18^{\circ} \mathrm{C}$, and sample endpoint core temperature is $-18^{\circ} \mathrm{C} .-29-18=$ freezer temperature is $-29^{\circ} \mathrm{C}$, and sample endpoint core temperature is $-18^{\circ} \mathrm{C}$. $-77-18=$ freezer temperature is $-77^{\circ} \mathrm{C}$, and sample endpoint core temperature is $-18^{\circ} \mathrm{C}$. $-29-29=$ freezer temperature is $-29^{\circ} \mathrm{C}$, and sample endpoint core temperature is $-29^{\circ} \mathrm{C}$. $-77-29=$ freezer temperature is $-77^{\circ} \mathrm{C}$, and sample endpoint core temperature is $-29^{\circ} \mathrm{C}$. $-77-$ $77=$ freezer temperature is $-77^{\circ} \mathrm{C}$, and sample endpoint core temperature is $-77^{\circ} \mathrm{C}$. ${ }^{* a-j}$ Treatments with different letters for freeze loss, thaw, loss and combined freeze/thaw loss are significantly different $(P \leq 0.05) . n=3$. Standard error for freeze loss $=0.05$, thaw loss $=0.06$, and combined loss $=0.09$.

described by [13]. The microscope was used to capture micrograph images of pores that are comparable to ice crystals formed within the tissue during freezing. Samples were first subjected to surface ice crystal damage analysis and then sliced in half to observe core ice crystal damage analysis. The instrument was set with an accelerating voltage of $20 \mathrm{kV}$ and a chamber pressure of $40 \mathrm{~Pa}$. Micrograph images were stored in the Quartz PCI Database of the Advanced Materials Research Lab under Clemson University.

2.7.2. Image J Ice Crystal Pore Size Analysis. The Image J $1.50 \mathrm{i}$ software, created by Wayne Rasband and the National Institutes of Health, was used to quantify ice crystal pore damage of the micrograph images obtained from the S-3400N Variable-Pressure Scanning Electron Microscope. Each image was set to a scale of known distance of $500 \mu \mathrm{m}$, dis- tance in pixels of 500, and a pixel aspect ratio of 1.0. Data gathered included area, area faction, and a fit ellipse, each to a decimal place of 3 . Each pore was analyzed based upon pore size from $50 \mu \mathrm{m}^{2}$ to infinity and circularity from 0 to 1.0. Based upon these settings, the software produced a total pore count, total pore area, average pore size, percent area, major and minor axis values, and pore angle data.

2.8. Moisture Content Determination. The peach samples were held at $100^{\circ} \mathrm{C}$ for $6 \mathrm{~h}$, and the percentage of moisture was calculated based on the weight loss. Moisture $(\%)=[($ weight $(\mathrm{g})$ before drying - weight (g) after drying) * 100]/ weight (g) before drying.

2.9. DPPH Free Radical Scavenging Assay. The antioxidant capacity was measured using the DPPH method as described 


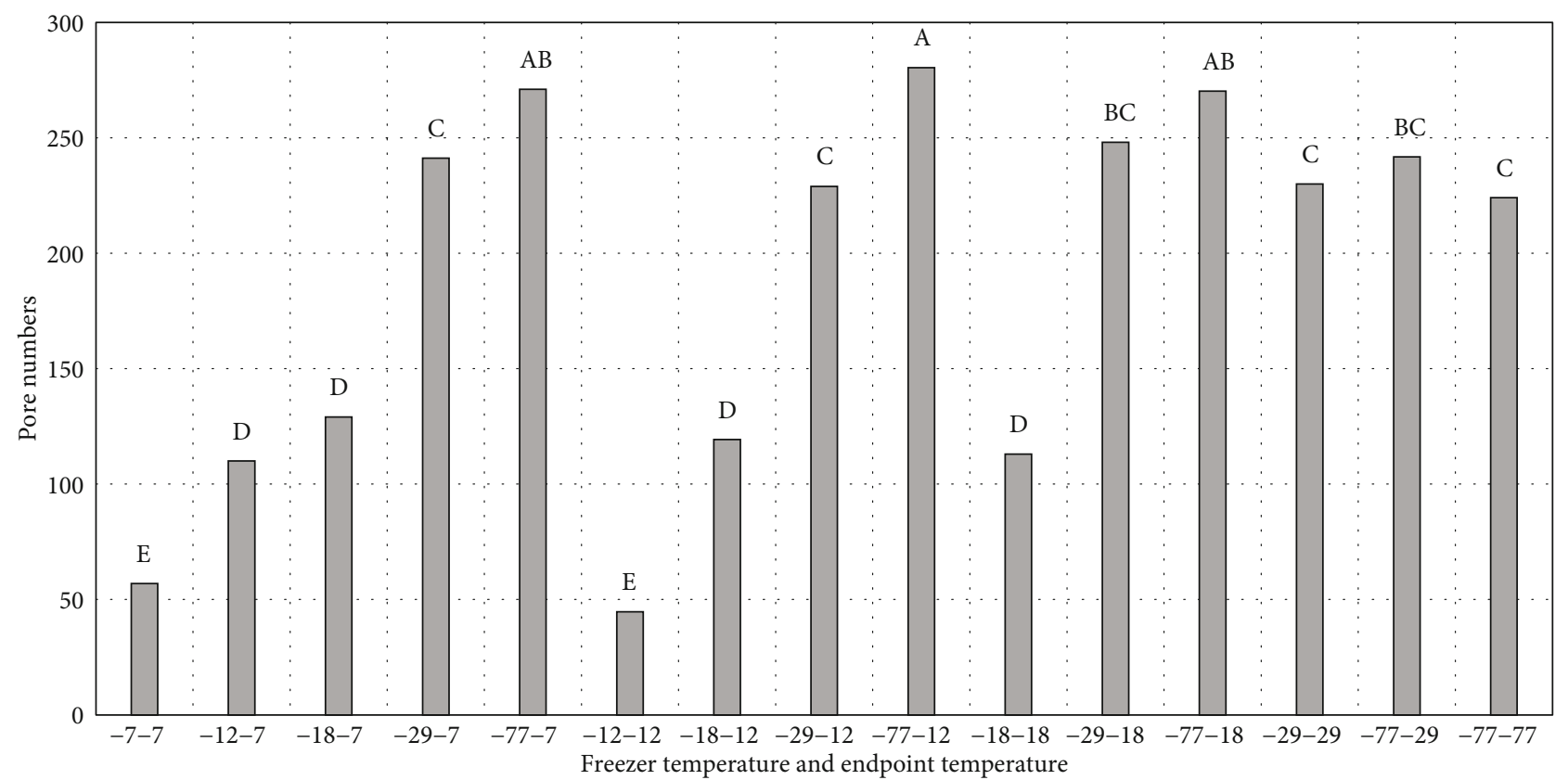

FIGURE 6: Pore numbers on fresh peach surfaces, frozen at different rates and to different endpoint temperatures. $-7-7=$ freezer temperature is $-7^{\circ} \mathrm{C}$, and sample endpoint core temperature is $-7^{\circ} \mathrm{C}$. $-12-7=$ freezer temperature is $-12^{\circ} \mathrm{C}$, and sample endpoint core temperature is $-7^{\circ} \mathrm{C}$. -18 $7=$ freezer temperature is $-18^{\circ} \mathrm{C}$, and sample endpoint core temperature is $-7^{\circ} \mathrm{C}$. $-29-7=$ freezer temperature is $-29^{\circ} \mathrm{C}$, and sample endpoint core temperature is $-7^{\circ} \mathrm{C}$. $-77-7=$ freezer temperature is $-77^{\circ} \mathrm{C}$, and sample endpoint core temperature is $-7^{\circ} \mathrm{C}$. $-12-12=$ freezer temperature is $-12^{\circ} \mathrm{C}$, and sample endpoint core temperature is $-12^{\circ} \mathrm{C}$. $-18-12=$ freezer temperature is $-18^{\circ} \mathrm{C}$, and sample endpoint core temperature is $-12^{\circ} \mathrm{C}$. $-29-12=$ freezer temperature is $-29^{\circ} \mathrm{C}$, and sample endpoint core temperature is $-12^{\circ} \mathrm{C} .-77-12=$ freezer temperature is $-77^{\circ} \mathrm{C}$, and sample endpoint core temperature is $-12^{\circ} \mathrm{C}$. $-18-18=$ freezer temperature is $-18^{\circ} \mathrm{C}$, and sample endpoint core temperature is $-18^{\circ} \mathrm{C}$. $-29-$ $18=$ freezer temperature is $-29^{\circ} \mathrm{C}$, and sample endpoint core temperature is $-18^{\circ} \mathrm{C}$. $-77-18=$ freezer temperature is $-77^{\circ} \mathrm{C}$, and sample endpoint core temperature is $-18^{\circ} \mathrm{C}$. $-29-29=$ freezer temperature is $-29^{\circ} \mathrm{C}$, and sample endpoint core temperature is $-29^{\circ} \mathrm{C}$. $-77-29=$ freezer temperature is $-77^{\circ} \mathrm{C}$, and sample endpoint core temperature is $-29^{\circ} \mathrm{C}$. $-77-77=$ freezer temperature is $-77^{\circ} \mathrm{C}$, and sample endpoint core temperature is $-77^{\circ} \mathrm{C} .{ }^{* \mathrm{a}-\mathrm{d}}$ Treatments with different letters for freeze loss and thaw loss are significantly different $(P \leq 0.05) . n=9$. Standard error for pore numbers $=9.09$.

by [14] with modifications. Briefly, fifteen grams of sliced peaches was dissolved with $100 \mathrm{ml}$ of $50 \%$ ethanol and blended for 30 seconds. The samples were centrifuged at $11000 \mathrm{rpm} / 15 \mathrm{~min}$ at $5^{\circ} \mathrm{C}$. L-Ascorbic acid standard was prepared by dissolving $0.0176 \mathrm{~g}$ of ascorbic acid in $100 \mathrm{ml}$ of $50 \%$ filtered water and $50 \%$ ethanol. DPPH was prepared by dissolving $0.008 \mathrm{~g}$ of DPPH in $100 \mathrm{ml}$ of $50 \%$ ethanol. $0.4 \mathrm{ml}$ from the sample was put in a tube and added $2 \mathrm{ml}$ of DPPH. The tubes were placed in a dark place for $30 \mathrm{~min} .0 .25 \mathrm{ml}$ was taken from each tube and placed in a microplate. The absorbance was measured using EPOCH spectrophotometer at $517 \mathrm{~nm}$, and the antioxidant activity was measured based on the standard curve of Lascorbic acid concentrations. The results were calculated, and the antioxidant capacity was expressed as $\mathrm{mg} / \mathrm{g}$.

2.10. Sensory Evaluation. The sensory evaluation was performed as described by [15]. The evaluation was performed in individual booths by a trained panel of 8 judges. The 8 judges were trained for two days for sensory evaluation of the color, texture, and flavor compared to fresh peach control samples. Eight lengthwise slice fresh and prefrozen samples after freezing were prepared and placed onto a white porcelain dish. The samples were tested within $5 \mathrm{~min}$ from cutting to ensure glossiness and avoid browning reactions. Each dish containing the sample was randomly marked by different numbers. The quality attribute evaluation was based on the acceptability which was determined using a hedonic scale marked with the following two anchors: $0.0=$ extremely dislike to $15.0=$ extremely like.

2.11. Statistical Analysis. The experiments (freezing rate and long-term storage) were each replicated 3 times starting on different days using different batches of peaches. The data were analyzed using a one-way analysis of variance (ANOVA), and statistical significance was at the 5\% level. For analyses where freezing had a significant treatment effect $(P \leq 0.05)$, significant differences were determined using multiple comparison tests and least significant difference (LSD) and Tukey's test for significance.

\section{Results and Discussion}

3.1. Experiment 1: Short-Term Freezing Effects on Peach Quality. Fresh peach slices were placed in freezers set at five different temperatures $\left(-7^{\circ} \mathrm{C},-12^{\circ} \mathrm{C},-18^{\circ} \mathrm{C},-29^{\circ} \mathrm{C}\right.$, and $-77^{\circ} \mathrm{C}$ ), then removed from each of the freezers when the core peach slice temperature reached each of the five temperatures. This created five different freezing times to reach $-77^{\circ} \mathrm{C}$, four different freezing times to reach $-12^{\circ} \mathrm{C}$, three 


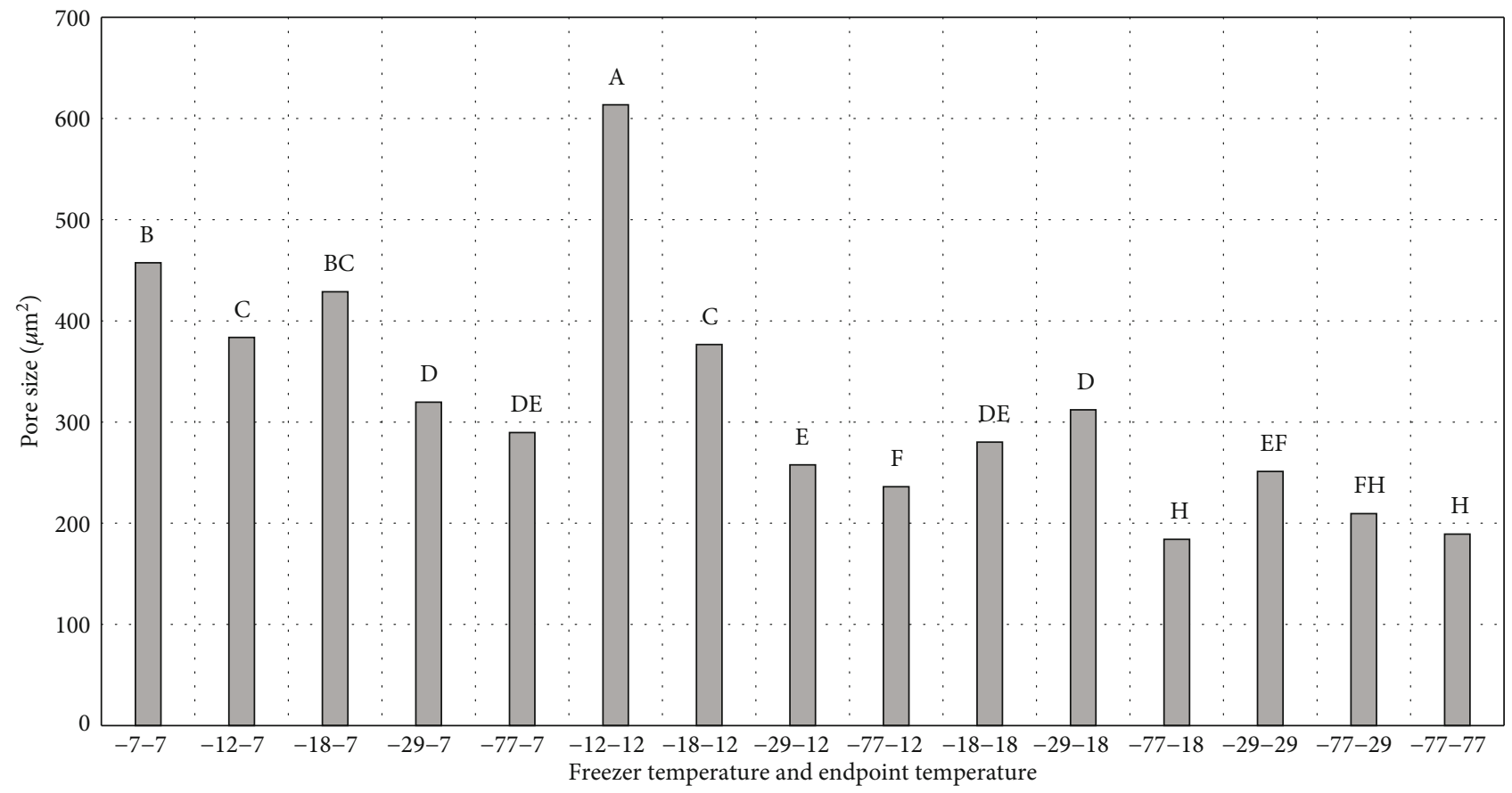

Figure 7: Pore size $\left(\mu \mathrm{m}^{2}\right)$ on peach slice surfaces. $-7-7=$ freezer temperature is $-7^{\circ} \mathrm{C}$, and sample endpoint core temperature is $-7^{\circ} \mathrm{C}$. -12 $7=$ freezer temperature is $-12^{\circ} \mathrm{C}$, and sample endpoint core temperature is $-7^{\circ} \mathrm{C}$. $-18-7=$ freezer temperature is $-18^{\circ} \mathrm{C}$, and sample endpoint core temperature is $-7^{\circ} \mathrm{C}$. $-29-7=$ freezer temperature is $-29^{\circ} \mathrm{C}$, and sample endpoint core temperature is $-7^{\circ} \mathrm{C}$. $-77-7=$ freezer temperature is $-77^{\circ} \mathrm{C}$, and sample endpoint core temperature is $-7^{\circ} \mathrm{C} .-12-12=$ freezer temperature is $-12^{\circ} \mathrm{C}$, and sample endpoint core temperature is $-12^{\circ} \mathrm{C}$. $-18-12=$ freezer temperature is $-18^{\circ} \mathrm{C}$, and sample endpoint core temperature is $-12^{\circ} \mathrm{C} .-29-12=$ freezer temperature is $-29^{\circ} \mathrm{C}$, and sample endpoint core temperature is $-12^{\circ} \mathrm{C}$. $-77-12=$ freezer temperature is $-77^{\circ} \mathrm{C}$, and sample endpoint core temperature is $-12^{\circ} \mathrm{C}$. -18 $18=$ freezer temperature is $-18^{\circ} \mathrm{C}$, and sample endpoint core temperature is $-18^{\circ} \mathrm{C}$. $-29-18=$ freezer temperature is $-29^{\circ} \mathrm{C}$, and sample endpoint core temperature is $-18^{\circ} \mathrm{C}$. $-77-18=$ freezer temperature is $-77^{\circ} \mathrm{C}$, and sample endpoint core temperature is $-18^{\circ} \mathrm{C}$. $-29-29=$ freezer temperature is $-29^{\circ} \mathrm{C}$, and sample endpoint core temperature is $-29^{\circ} \mathrm{C}$. $-77-29=$ freezer temperature is $-77^{\circ} \mathrm{C}$, and sample endpoint core temperature is $-29^{\circ} \mathrm{C}$. $-77-77=$ freezer temperature is $-77^{\circ} \mathrm{C}$, and sample endpoint core temperature is $-77^{\circ} \mathrm{C}$. ${ }^{* a-h}$ Treatments with different letters for freeze loss and thaw loss are significantly different $(P \leq 0.05) . n=9$. Standard error for pore size $=16.73$.

TABLE 1: Lightness $\left(L^{*}\right)$ and redness $\left(a^{*}\right)$ for fresh peaches frozen at different rates and to different endpoint temperatures.

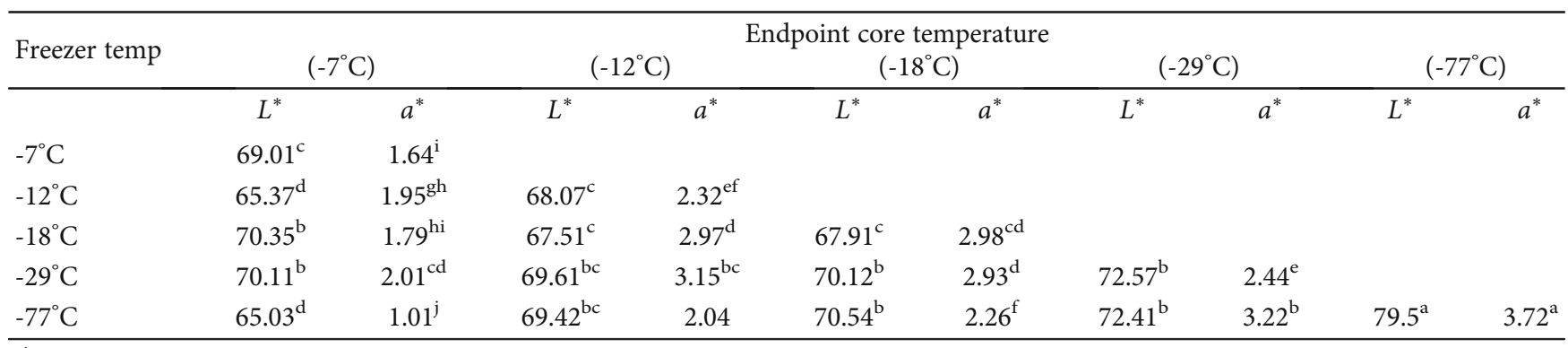

${ }^{\mathrm{a}-\mathrm{j}}$ Values for each color parameter with different letters are significantly different $(P \leq 0.05) \cdot n=9$. Standard error for $L=0.68$ and for $a^{*}=0.06$.

different freezing times to reach $-18^{\circ} \mathrm{C}$, and two different freezing times to reach $-29^{\circ} \mathrm{C}$ : culminating in 15 different freezing.

Freezing rate $\left({ }^{\circ} \mathrm{C} / \mathrm{h}\right)$ was calculated by the following: the difference between initial and final value of product temperature divided by freezing time [16]. This generated different freezing rates (Figure 4) ranging from $0.07^{\circ} \mathrm{C} /$ minute for freezing to $-7^{\circ} \mathrm{C}$ in the $-7^{\circ} \mathrm{C}$ freezer to $1.8^{\circ} \mathrm{C} /$ minute for freezing to $29^{\circ} \mathrm{C}$ in the $-77^{\circ} \mathrm{C}$ freezer.
Peaches frozen in $-7^{\circ} \mathrm{C}$ and $-12^{\circ} \mathrm{C}$ freezers had significantly higher freeze and thaw loss than peaches frozen in $-29^{\circ} \mathrm{C}$ and $-77^{\circ} \mathrm{C}$ (Figure 5). This was expected since the freezing rate at $-77^{\circ} \mathrm{C}$ and $-29^{\circ} \mathrm{C}$ was significantly faster than in the $-7^{\circ} \mathrm{C}$ and $-12^{\circ} \mathrm{C}$ freezers (Figure 4). During the four stages of the freezing, product temperature first drops to freezing point, then before ice crystal formation begins the product temperature falls below the freezing point (supercooling) [17]. The third stage of ice crystal 


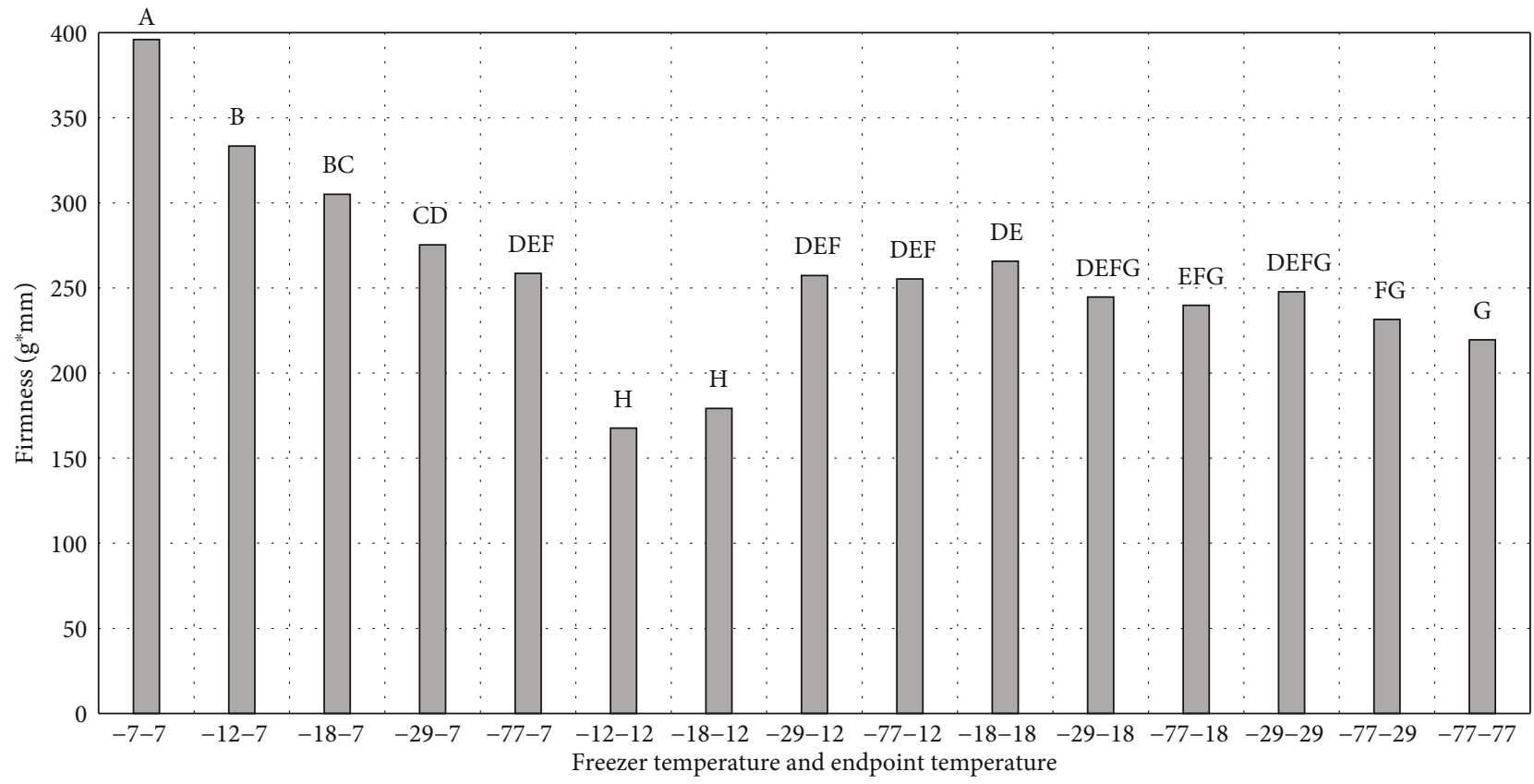

Figure 8: Razor blade shear $(\mathrm{g} * \mathrm{~mm})$ for fresh peach slices frozen at different rates and to different endpoint temperatures. $-7-7=$ freezer temperature is $-7^{\circ} \mathrm{C}$, and sample endpoint core temperature is $-7^{\circ} \mathrm{C} .-12-7=$ freezer temperature is $-12^{\circ} \mathrm{C}$, and sample endpoint core temperature is $-7^{\circ} \mathrm{C}$. $-18-7=$ freezer temperature is $-18^{\circ} \mathrm{C}$, and sample endpoint core temperature is $-7^{\circ} \mathrm{C}$. $-29-7=$ freezer temperature is $-29^{\circ} \mathrm{C}$, and sample endpoint core temperature is $-7^{\circ} \mathrm{C}$. $-77-7=$ freezer temperature is $-77^{\circ} \mathrm{C}$ and sample endpoint core temperature is $-7^{\circ} \mathrm{C}$. $-12-12=$ Freezer temperature is $-12^{\circ} \mathrm{C}$, and sample endpoint core temperature is $-12^{\circ} \mathrm{C} .-18-12=$ freezer temperature is $-18^{\circ} \mathrm{C}$, and sample endpoint core temperature is $-12^{\circ} \mathrm{C}$. $-29-12=$ freezer temperature is $-29^{\circ} \mathrm{C}$, and sample endpoint core temperature is $-12^{\circ} \mathrm{C}$. $-77-12=$ freezer temperature is $-77^{\circ} \mathrm{C}$, and sample endpoint core temperature is $-12^{\circ} \mathrm{C}$. $-18-18=$ freezer temperature is $-18^{\circ} \mathrm{C}$, and sample endpoint core temperature is $-18^{\circ} \mathrm{C}$. $-29-18=$ freezer temperature is $-29^{\circ} \mathrm{C}$, and sample endpoint core temperature is $-18^{\circ} \mathrm{C}$. $-77-18=$ freezer temperature is $-77^{\circ} \mathrm{C}$, and sample endpoint core temperature is $-18^{\circ} \mathrm{C}$. $-29-29=$ freezer temperature is $-29^{\circ} \mathrm{C}$, and sample endpoint core temperature is $-29^{\circ} \mathrm{C}$. $-77-29=$ freezer temperature is $-77^{\circ} \mathrm{C}$, and sample endpoint core temperature is $-29^{\circ} \mathrm{C}$. $-77-77=$ freezer temperature is $-77^{\circ} \mathrm{C}$, and sample endpoint core temperature is $-77^{\circ} \mathrm{C}$. ${ }^{* \mathrm{a}-\mathrm{d}}$ Treatments with different letters for freeze loss and thaw loss are significantly different $(P \leq 0.05) . n=9$. Standard error for shear $=10.99$.

TABLe 2: Ascorbic acid equivalent antioxidant capacity (mg/g peaches, wet basis) for thawed fresh peaches frozen at different temperatures.

\begin{tabular}{lcccc}
\hline Freezer temp & $\left(-7^{\circ} \mathrm{C}\right)$ & $\left(-12^{\circ} \mathrm{C}\right)$ & $\begin{array}{c}\text { Endpoint core temperature } \\
\left(-18^{\circ} \mathrm{C}\right)\end{array}$ & $\left(-29^{\circ} \mathrm{C}\right)$ \\
\hline$-7^{\circ} \mathrm{C}$ & $31.53 \pm 1.89$ & & & \\
$-12^{\circ} \mathrm{C}$ & $32.64 \pm 1.24$ & $32.36 \pm 2.61$ & & \\
$-18^{\circ} \mathrm{C}$ & $32.53 \pm 1.76$ & $32.05 \pm 2.24$ & $32.09 \pm 2.57$ & $32.43 \pm 2.40$ \\
$-29^{\circ} \mathrm{C}$ & $31.54 \pm 2.09$ & $32.33 \pm 2.57$ & $31.88 \pm 2.49$ & $31.39 \pm 2.57$ \\
$-77^{\circ} \mathrm{C}$ & $31.47 \pm 2.33$ & $31.19 \pm 2.81$ & $31.71 \pm 2.33$ & $31.84 \pm 2.89$ \\
\hline
\end{tabular}

Standard error for antioxidant capacity $=0.79 . n=9$.

formation (phase change) is the longest and most energy intensive stage. The final stage of freezing is lowering the product temperature to the final storage temperature [17]. Rapid freezing leads to insufficient time for loss of water from the plant cellular structure and smaller ice crystals form within the cell compared to slower freezing rates. Slow freezing allows more water to move outside plant cell structure to form large ice crystals, damaging the plant structure resulting in greater drip loss during freezing and thawing [18]. Because of the cell wall damage during freezing, the water cannot return to the cells upon thawing but, rather, becomes drip loss [19]. Three factors that influence drip loss are high internal pressure in the product, formation of ice crystals in the product, and the irreversible removal of water from plant cells. An increase in drip loss indicates a greater loss of liquid cellular components and is exacerbated by enzyme-catalyzed disruption of cell walls and membrane damage during freezing and frozen storage [20]. Ice crystal growth may also occur during frozen storage due to freezer temperature cycling during defrosting leading to larger crystal formation, which will damage and rupture cell walls [21]. 


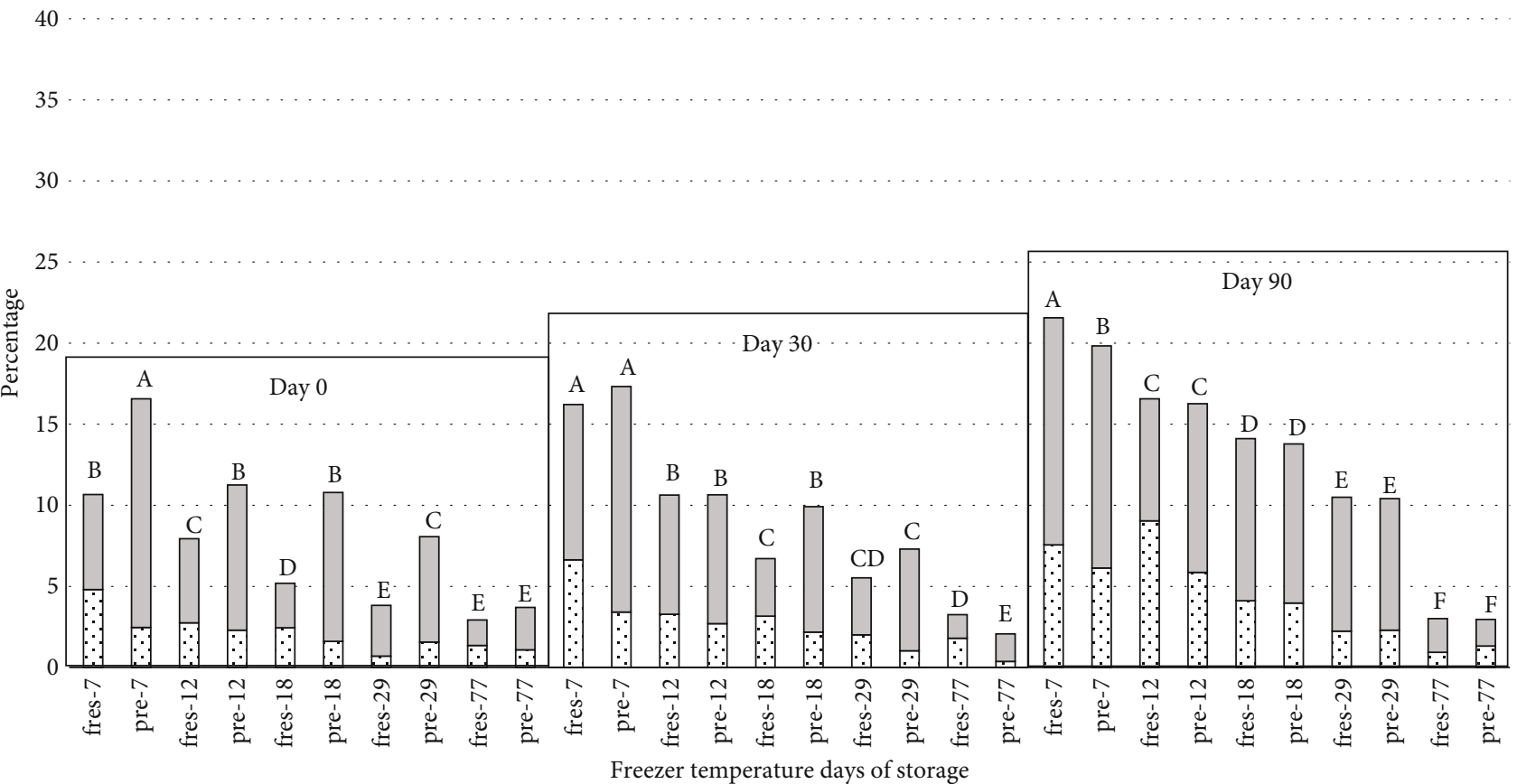

Freeze loss

$\square$ Thaw loss

FIGURE 9: Weight loss during freezing and thawing and combined weight loss for fresh and prefrozen peach slices stored at different temperatures for 0,30 , and 90 days. $n=3$. fres: fresh peaches; pre: prefrozen peaches. ${ }^{\mathrm{a}-\mathrm{f}}$ Values with different letters within each sampling day are significantly different $(P \geq 0.05)$. Standard error for combined freeze and thaw loss $=1.23$.

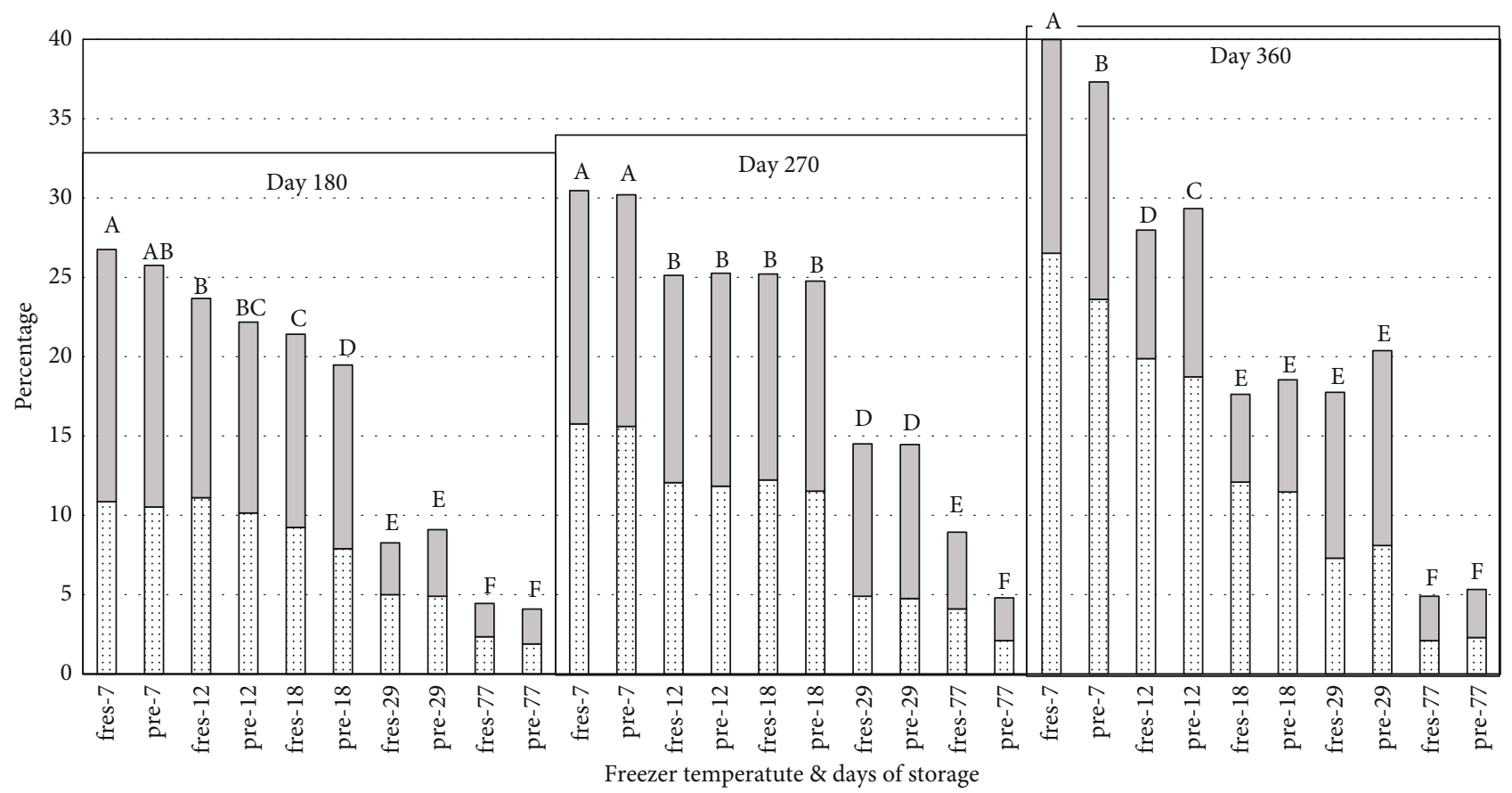

$\therefore$ Freeze loss

$\square$ Thaw loss

Figure 10: Weight loss during freezing and thawing and combined weight loss for fresh and prefrozen peach slices stored at different temperatures for 180, 270, and 360 days. $n=3$. fres: fresh peaches; pre: prefrozen peaches. ${ }^{\mathrm{a}-\mathrm{g}}$ Values with different letters within each sampling day are significantly different $(P \geq 0.05)$. Standard error for combined freeze and thaw loss $=1.23$. 


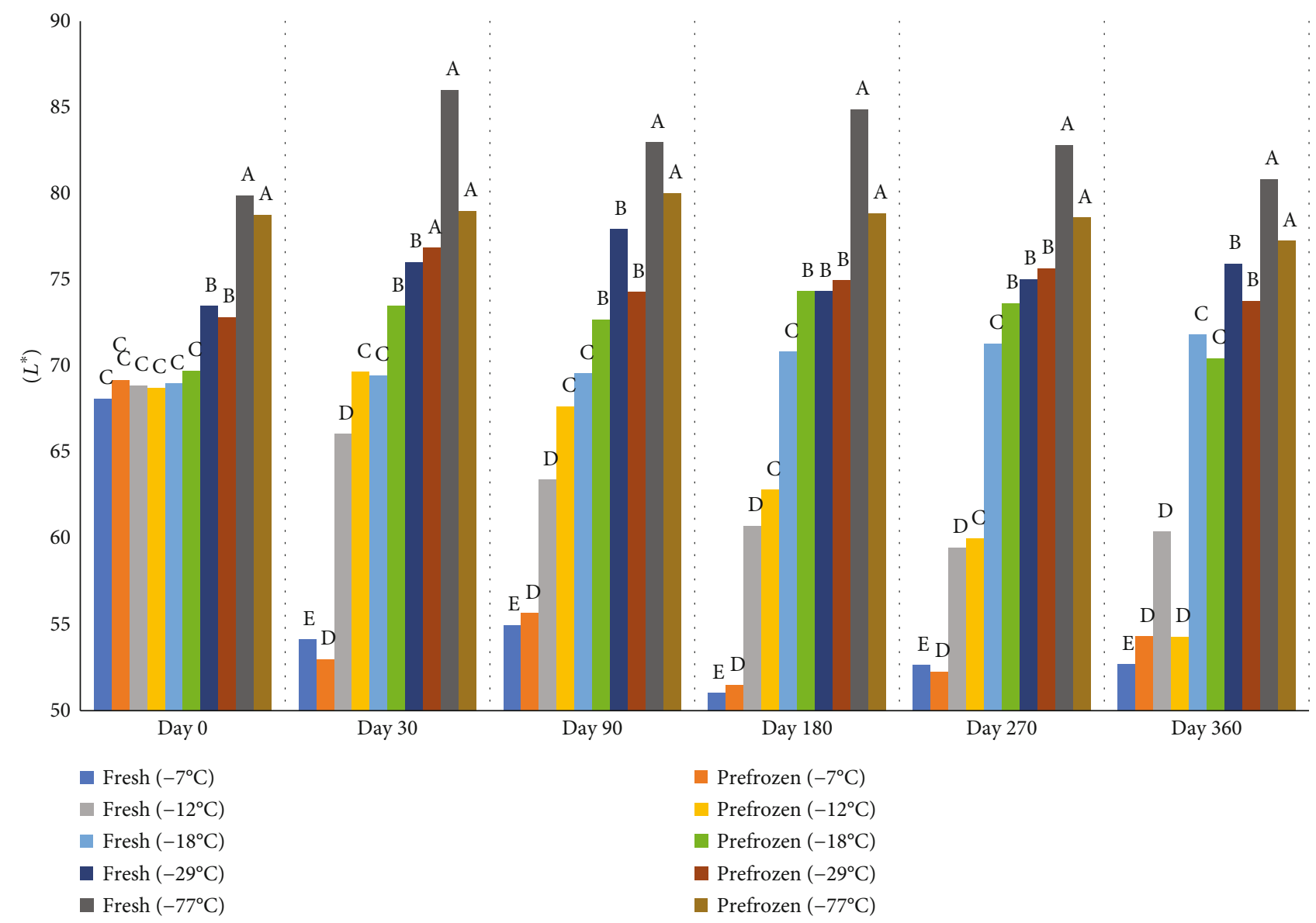

Figure 11: Average lightness $\left(L^{*}\right)$ of fresh and prefrozen peaches held at different temperatures for 1 year. $n=9 .{ }^{a-e}$ Fresh samples within sampling day with different superscripts are significantly different $(P<0.05)$. ${ }^{\mathrm{a} e \mathrm{e}}$ Prefrozen samples within sampling day with different superscripts are significantly different $(P<0.05)$.

As previously discussed, ice crystal pore size and the number of ice crystals formed are directly impacted by freezing rate and reflected in drip loss. As expected, the surface ice crystal pore size was inversely related to freezing rate thus greater for peaches frozen at $-7^{\circ} \mathrm{C}$ than $-77^{\circ} \mathrm{C}$ while the pore numbers were directly related to freezing rate (Figures 6 and 7). And as just discussed, slower freezing caused large ice crystal to be formed in peaches, while fast freezing resulted in smaller ice crystal which leading to less damage to the peaches during freezing. Smaller ice crystals result in better frozen food quality while slow freezing creates large ice crystals particularly in extracellular space and causes tissue damage. Rapid freezing produces numerous small ice crystals that are more uniformly distributed both in intracellular and extracellular spaces [22, 23]. Rapid freezing is useful in fruit and vegetable products; however, temperature fluctuations during storage could cause recrystallization and loss of quality in frozen product [23].

Peaches were generally lighter (higher $L^{*}$ ) and redder (higher $a^{*}$ ) in lower temperature freezers (faster freezing rates) compared to the higher freezer temperatures with slower freezing rate (Table 1 ). Variation in $b^{*}$ values resulted in a lack of significance for the freezing treatments. The chroma values ranged between 27.9 and 30.1, and hue ranged between 82.6 and 88.9 for all treatments with no freezing effect trends. Slower freezing resulted in peaches with higher shear force values compared to faster freezing rates (Figure 8). Lightness, redness, and shear force were directly related to freezer temperature/freezing rates reflecting the retention of water in the cellular structure of peaches. Darker appearance and increased firmness were likely due to formed larger ice crystals formed during slow freezing, which damaged the cellular reducing the turgor pressure and increasing firmness values of the samples.

Sensory panelists judged peaches similar to fresh peaches in appearance. But after a 24 -hour thawing (at $3.33^{\circ} \mathrm{C}$ ) cycle, all peaches exhibited browning despite prefreezing treatment with $2 \%$ of ascorbic acid. Freezing causes cell damage to the delicate organelles and membrane structures within the fruit. As one consequence, enzyme systems may be dislocated and released from organelles leading to enzyme activity with a variety of deteriorative reactions and effects, including browning. Moreover, water loss from the intracellular peach components impact turgidity increasing the intracellular solute concentration affecting $\mathrm{pH}$ and ionic strength on the unfrozen portion of the peach tissue. This concentration of solutes will negatively affect product quality $[24,25]$. Browning of frozen peaches during thawing is caused by a combination 


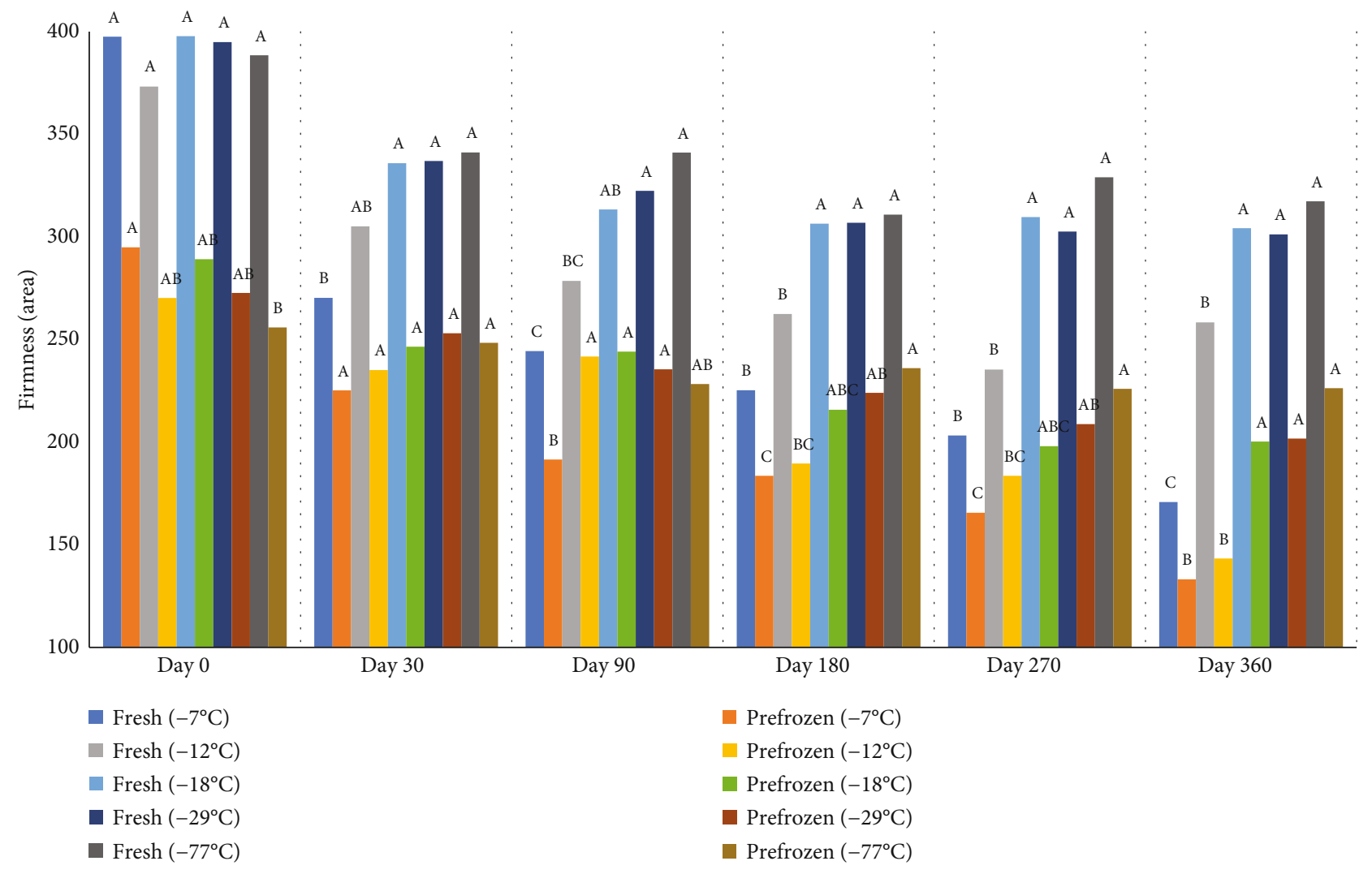

FIGURE 12: Average firmness (area $\mathrm{g} * \mathrm{sec}$ ) of fresh and prefrozen peaches frozen at different temperatures and held for one year. ${ }^{\mathrm{a}-\mathrm{e}}$ Fresh samples within sampling day with different superscripts are significantly different $(P<0.05) . n=9$. Standard error $=16.9{ }^{a-e}$ Prefrozen samples within sampling day with different superscripts are significantly different $(P<0.05) . n=9$. Standard error $=13.9$.

of (1) damage of chloroplasts and chromoplasts by ice formation and volume expansion; (2) development of enzymatic browning; (3) changes in natural colorants, including the conversion of chlorophylls (green) to pheophytins (brown), complexation of anthocyanins and other pigments from leukoanthocyanins, and degradation of carotenoids [26, 27].

There was no difference between treatments for ascorbic acid antioxidant capacity (Table 2). The loss of ascorbic acid can be caused by long-term storage or high temperatures or physical damage to fruit by chill injury [28]. Sahari et al. [29] found no effect of freezing rate on vitamin C content of Iranian strawberries thus changes in antioxidant capacity in frozen foods is expected to be minimal.

\subsection{Experiment 2. Long-Term Freezing Effects on Peach} Quality. Weight loss for peaches significantly increased for all storage temperatures over the 1-year storage study; however, the increase in weight loss was generally greater for peaches stored at higher temperatures compared peaches in lower temperatures (Figures 9 and 10). Except for day 0, the weight loss due to freezing and thawing did not differ between prefrozen and fresh peaches. Peaches frozen at $77^{\circ} \mathrm{C}$ had lower in weight loss than peaches frozen and held at all other temperatures on days $30,90,180,270$, and 360. Also, peaches frozen at $-29^{\circ} \mathrm{C}$ had lower in weight loss than peaches held at $18^{\circ} \mathrm{C}, 12^{\circ} \mathrm{C}$, and $7^{\circ} \mathrm{C}$ after $90,180,270$, and 360 days of storage. There was no significant difference in weight loss for peaches held at $-7^{\circ} \mathrm{C}$ and $-12^{\circ} \mathrm{C}$ on days 90 ,
180,270 , and 360 . Other researchers have also observed the weight loss of food after thawing [30-32]. Rao [30] found a direct relationship between weight loss and the amount of pectic substances, sugars, titratable acidity, ash, and minerals which found in the drip. Pukszta and Palich [31] indicated that weight loss in frozen strawberries increased with the length of and temperature variations during storage. Gormley [32] indicated that weight loss can be related to the loss of turgidity in fresh fruits due to the imbalance between the continuous loss of water by transpiration and lack of water uptake.

There was a direct relationship between lightness and lower freezing temperature; thus, the peaches frozen at lower temperatures became darker during storage (Figure 11). Peaches frozen at $7^{\circ} \mathrm{C}$ were darker than peaches frozen at all other temperatures at 30 days of storage. By 180 days of storage, peaches frozen at both $7^{\circ} \mathrm{C}$ and $12^{\circ} \mathrm{C}$ were darker than peaches frozen at the other temperatures. Furthermore, peaches held at $-77^{\circ} \mathrm{C}$ were lighter than peaches in $-29^{\circ} \mathrm{C}$ on days $30,90,180,270$, and 360 , and peaches in $-29^{\circ} \mathrm{C}$ were lighter than peaches held at $18^{\circ} \mathrm{C}, 12^{\circ} \mathrm{C}$, and $7^{\circ} \mathrm{C}$ on days 30,90 , 180,270 , and 360 . All samples enzymatically browned upon thawing after one week at freezer of $-7^{\circ} \mathrm{C}$; therefore, frozen peaches are best used for applications where they can be used in the frozen state and before thawing.

Firmness of peaches generally decreased during frozen storage regardless of the freezer temperature (Figure 12). Furthermore, fresh peaches were more firm than prefrozen 


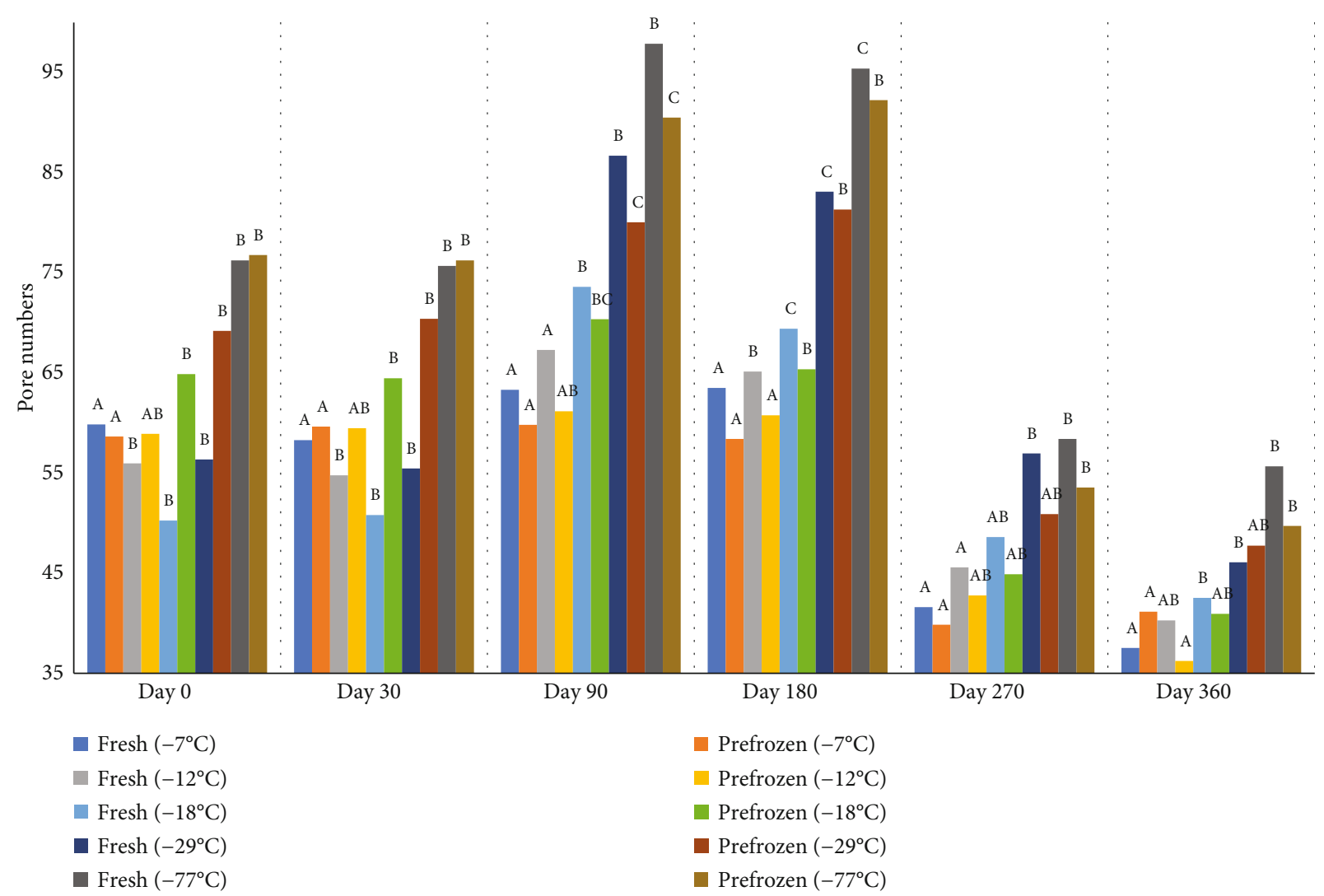

FIGURE 13: Scanning electron microscopy (pore numbers) of fresh and prefrozen peaches frozen and held for one year at different temperatures. $n=9$. ${ }^{\text {a-e }}$ Fresh samples within sampling day with different superscripts are significantly different $(P<0.05)$. Standard error $=5.7$. ${ }^{\mathrm{a} e}$ Prefrozen samples within sampling day with different superscripts are significantly different $(P<0.05)$. Standard error $=5.0$.

peaches at all freezer temperatures. There was no difference in the firmness between peaches frozen at $-77^{\circ} \mathrm{C},-29^{\circ} \mathrm{C}$, and $-18^{\circ} \mathrm{C}$ on days $30,90,180,270$, and 360 , and peaches in freezers at $-29^{\circ} \mathrm{C}$ and $-18^{\circ} \mathrm{C}$ were firmer than peaches held at $-12^{\circ} \mathrm{C}$ and $-7^{\circ} \mathrm{C}$ on days 180,270 , and 360 . The firmness of peaches frozen at $-7^{\circ} \mathrm{C}$ was lower than all other freezing temperatures. Higher freezer temperatures such as $-12^{\circ} \mathrm{C}$ and $-7^{\circ} \mathrm{C}$ will damage peaches' cell membranes caused by ice crystal volume expansion that reduces product integrity after thawing resulting in excessive drainage [33]. Lower freezing temperatures such as $-77^{\circ} \mathrm{C},-29^{\circ} \mathrm{C}$, and $-18^{\circ} \mathrm{C}$ can form a protective ice layer on the peach surface minimizing volume expansion during freezing [34]. Firmness is also related to the pectin content which has both water-soluble and insoluble fractions [35]. Therefore, loss of watersoluble pectin during thawing will reduce peach firmness [5].

The number of pores decreased, and the size of pores increased during storage at all freezer temperatures (Figures 13 and 14, respectively). Changes in lightness and firmness reflect the changes in pore size and number. The larger pore size mirror decreases in firmness and lightness of peaches due to cell membrane damage. There was no difference in pore numbers for peaches held at $-77^{\circ} \mathrm{C}$ and $-29^{\circ} \mathrm{C}$ on days $30,90,180,270$, and 360 . There was also no difference in peach pore numbers between freezers $-29^{\circ} \mathrm{C}$ and $-18^{\circ} \mathrm{C}$ on days $30,90,180,270$, and 360 . The peaches frozen at lower temperatures of $-77^{\circ} \mathrm{C}$ and $-29^{\circ} \mathrm{C}$ had smaller pores than other freezers. But, the growth of ice crystal ruptures, pushes, and compresses the peaches cells. Micrographs of peach surfaces frozen from the fresh state and held from the commercially prefrozen state are visually smaller for the peach samples held at $-77^{\circ} \mathrm{C}$ and $-29^{\circ} \mathrm{C}$ compared to those held at $-7^{\circ} \mathrm{C}$ (Figure 15). The nucleation of ice and the numbers and sizes of ice crystals formed depend on the freezing rate; slower rates of freezing will produce less nucleation, larger ice crystals, and more dislocation (migration) of water and ice; hence, the ice accumulates in large areas. Alternatively, faster rates will produce more nucleation, but smaller ice crystals [5].

The antioxidant capacity of peaches significantly decreased over time (Figure 16). Peaches stored at $-77^{\circ} \mathrm{C}$ and $-29^{\circ} \mathrm{C}$ retained higher antioxidant capacity than other freezers in days $30,90,180,270$, and 360 . There was no difference in peach antioxidant capacity held at $-7^{\circ} \mathrm{C}$ and $-12^{\circ} \mathrm{C}$ on days $90,180,270$, and 360 . However, not just ascorbic acid is responsible for the antioxidant properties of peaches but also phenolic content. The main bioactive compounds in fruits are vitamins A and C, carotenoids, and phenolics. These compounds give the foods their antioxidant properties [37]. De Ancos et al. [38] found that freezing process slightly affected total phenolic content in raspberry and a continuous decrease in the total ellagic acid content. The losses were attributed to the enzyme polyphenol oxidase released from the cell wall of the fruit during storage. The 


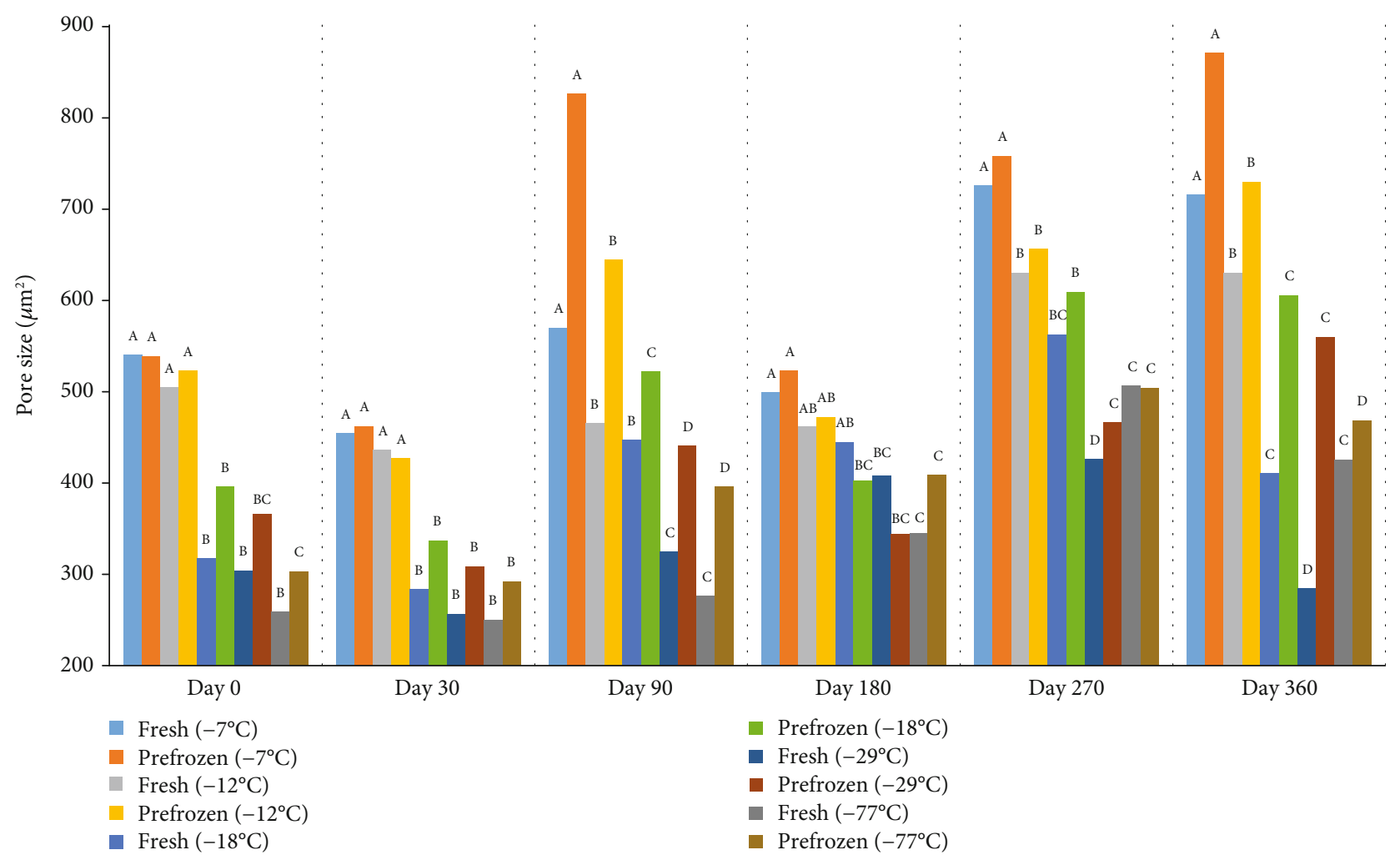

FiguRE 14: (pore size $\mu \mathrm{m}^{2}$ ) $500 \mu \mathrm{m}$ of fresh and prefrozen peaches frozen and held for one year at different temperatures. $n=9{ }^{\mathrm{a}-\mathrm{e}}$ Fresh samples within sampling day with different superscripts are significantly different $(P<0.05)$. Standard error $=28.1{ }^{a-e}$ Prefrozen samples within sampling day with different superscripts are significantly different $(P<0.05)$. Standard error $=36.8$.
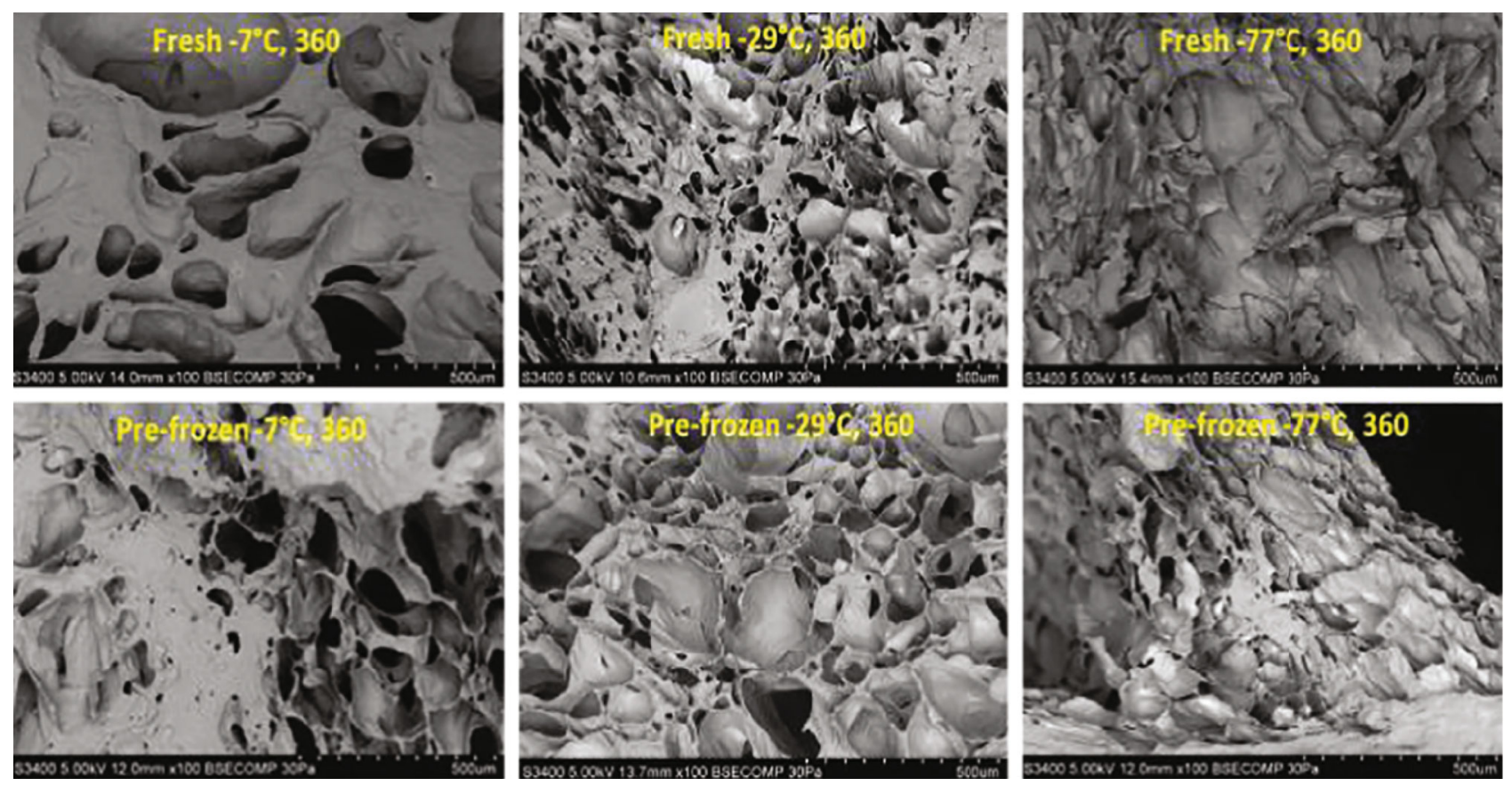

FIGURE 15: Scanning electron microscopy (pore size $\left.\mu \mathrm{m}^{2}\right)(500 \mu \mathrm{m})$ of fresh and prefrozen peaches surfaces. $n=9$.

phenolic content in the peach pulp varies which is from 0.82 to $6.52 \mathrm{mg}$ gallic acid equivalent [39]. The major loss of ascorbic acid observed at freezers $-7^{\circ} \mathrm{C}$ and $12^{\circ} \mathrm{C}$ because of peach weight loss during thawing which decreased the level of ascorbic acid. Ascorbic acid is water soluble which could be affected by ice crystal formation. The degradation of 


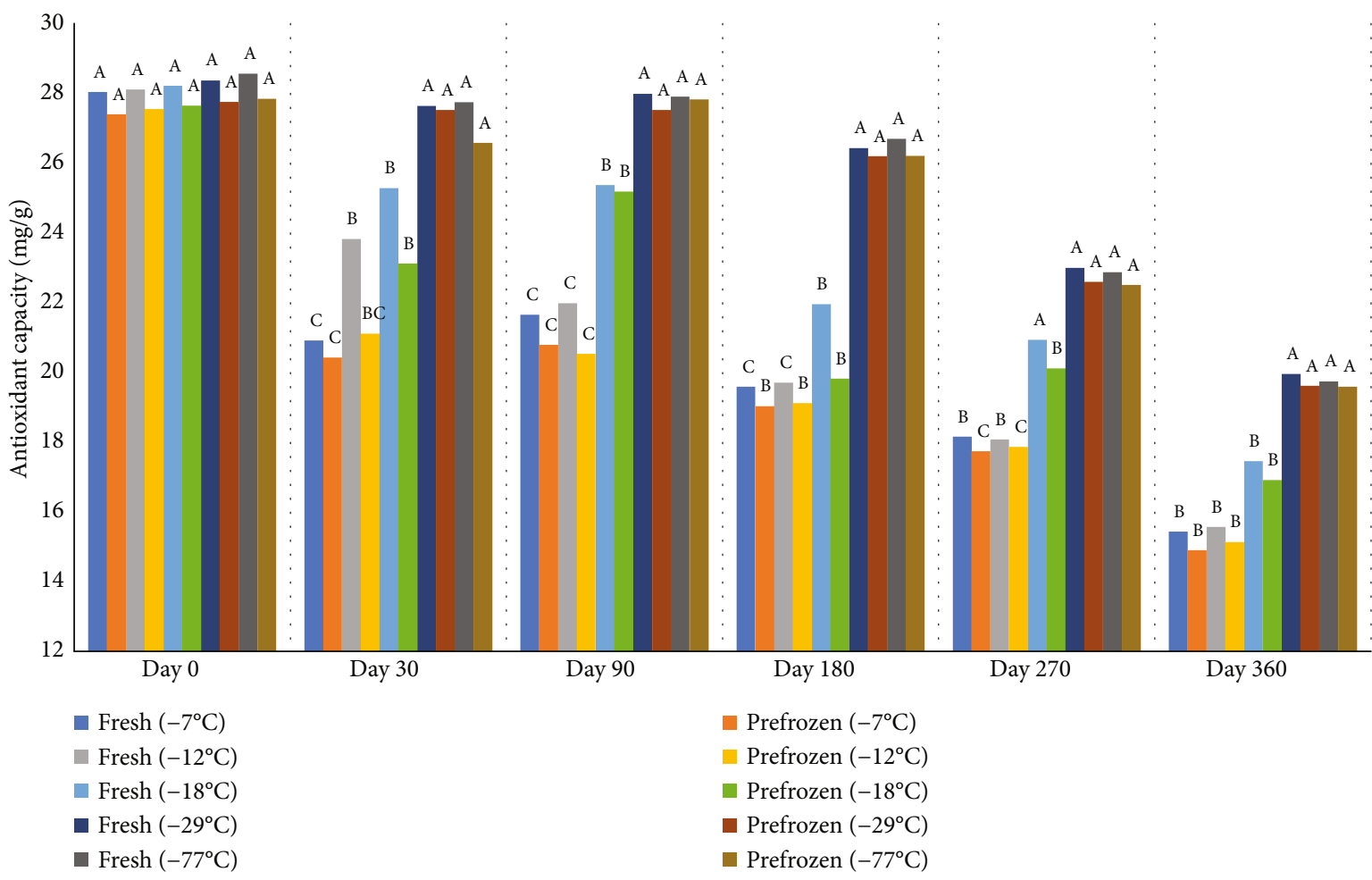

FIGURE 16: Ascorbic acid equivalent antioxidant capacity $(\mathrm{mg} / \mathrm{g})$ of fresh and prefrozen peaches frozen and held for one year at different temperatures. $n=9$. ${ }^{\mathrm{a}-\mathrm{e}}$ Fresh samples within sampling day with different superscripts are significantly different $(P<0.05)$. Standard error $=2.1{ }^{\mathrm{a}-\mathrm{e}}$ Prefrozen samples within sampling day with different superscripts are significantly different $(P<0.05)$. Standard error $=1.8$.

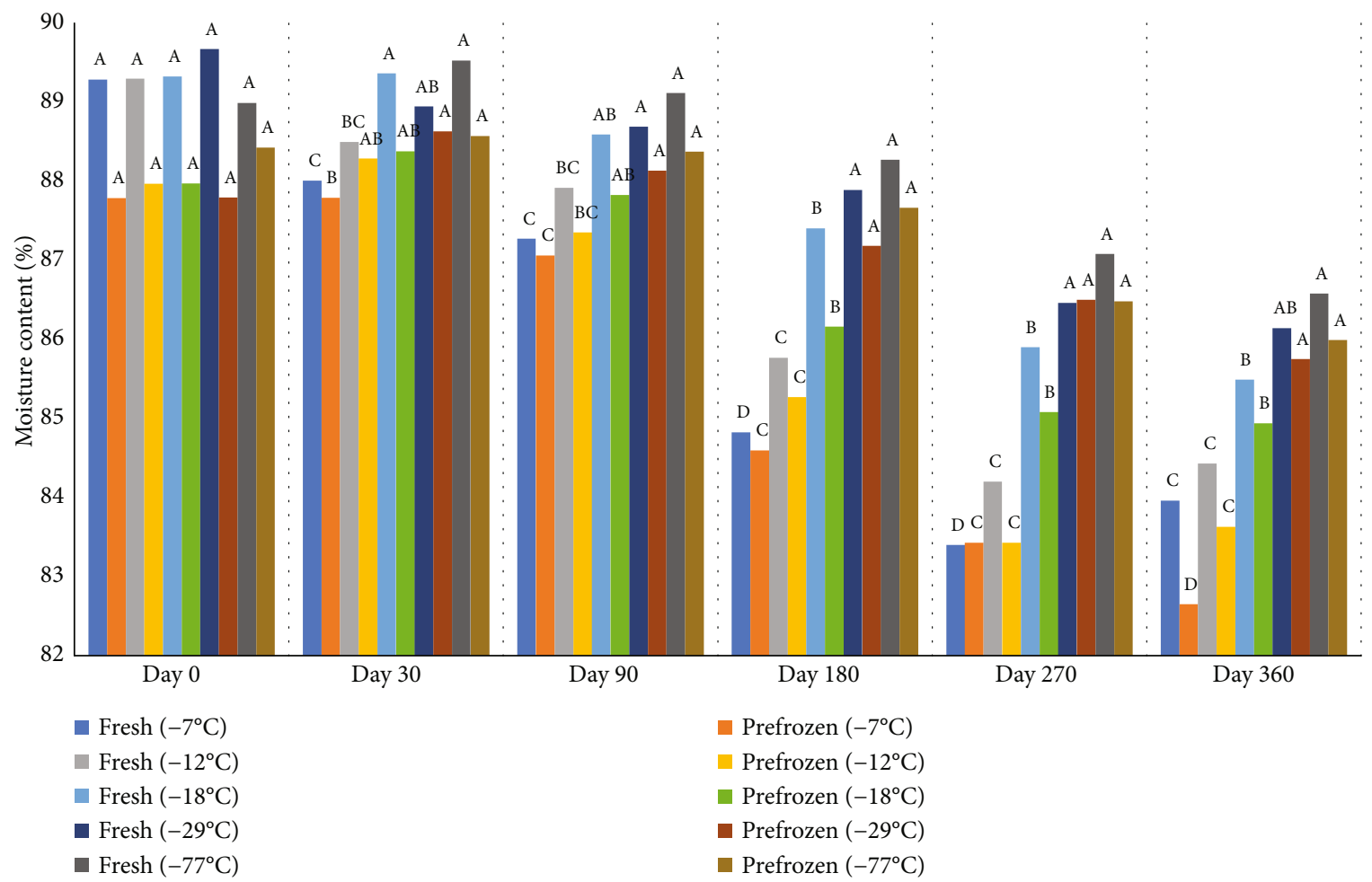

FIGURE 17: Average moisture content (\%) of fresh and prefrozen peaches frozen and held for one year at different temperatures. $n=9 .{ }^{\mathrm{a}-\mathrm{e}}$ Fresh samples within sampling day with different superscripts are significantly different $(P<0.05)$. Standard error for fresh peaches $=4.5$. ${ }^{a-}$ ${ }^{e}$ Prefrozen samples within sampling day with different superscripts are significantly different $(P<0.05)$. Standard error for prefrozen peaches $=3.6$. 


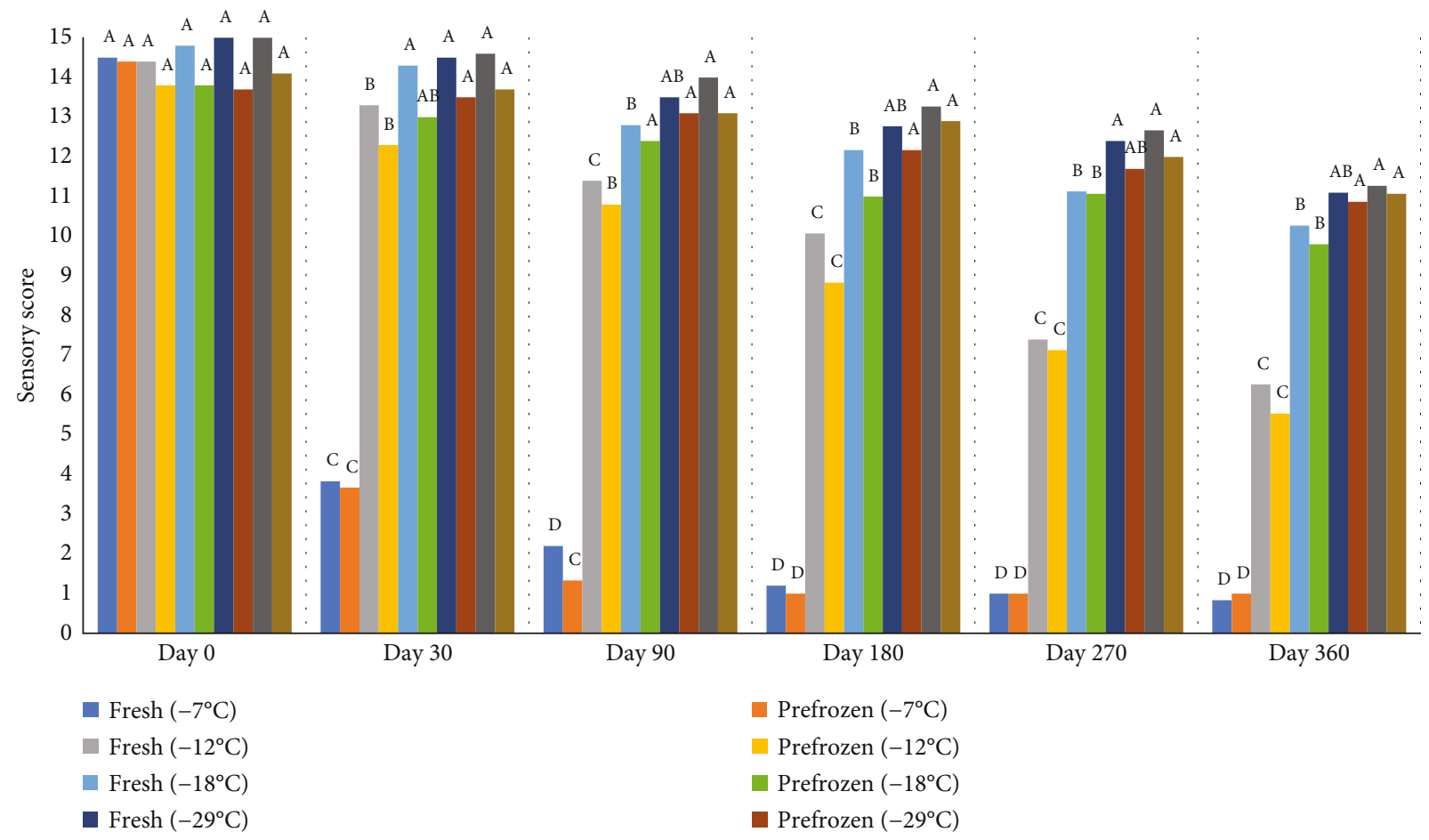

FiguRE 18: Sensory evaluation of fresh and prefrozen peaches frozen and held for one year at different temperatures. $n=9(0=$ extremely dislike to $15=$ extremely like). $n=3 .{ }^{a-e}$ Fresh samples within sampling day with different superscripts are significantly different $(P<0.05)$. Standard error $=0.4 .{ }^{\text {a-d }}$ Prefrozen samples within sampling day with different superscripts are significantly different $(P<0.05)$. Standard error $=0.3$.

ascorbic acid is affected during frozen storage by several factors such as pretreatments, type of food and packaging, freezing process, time, and temperature conditions [40]. Oxidation of ascorbic acid may be enzymatic or nonenzymatic. The enzyme mainly causing loss of vitamin $\mathrm{C}$ is ascorbate oxidase [37]. Many studies indicated that stability of ascorbic acid is higher in some fruits such as berries, citrus, and tomato. when the frozen storage temperature decreases [40, 41]. Sahari et al. [29] found that the loss of vitamin C was considerable at $-12^{\circ} \mathrm{C}$; however, vitamin $\mathrm{C}$ was higher at $-18^{\circ} \mathrm{C}$ and $-24^{\circ} \mathrm{C}[29]$.

Moisture content of peaches decreased over time and was higher in peaches frozen and held at lower temperature (Figure 17). Lower moisture mirrored the loss of antioxidant capacity which may be due in part to the loss of water-soluble vitamins such as ascorbic acid. There was no difference in moisture content for peaches held at $-77^{\circ} \mathrm{C}$ and $-29^{\circ} \mathrm{C}$ on days $30,90,180,270$, and 360 . Peaches in $-77^{\circ} \mathrm{C}$ also had higher moisture content than peaches held in $-18^{\circ} \mathrm{C},-12^{\circ} \mathrm{C}$, and $-7^{\circ} \mathrm{C}$ freezers on days 180,270 , and 360 .

Sensory scores for frozen peaches decreased during storage; however, peaches stored at $-18^{\circ} \mathrm{C},-29^{\circ} \mathrm{C}$, and $-77^{\circ} \mathrm{C}$ retained relatively high sensory scores through the one year storage cycle while peaches stored at $-12^{\circ} \mathrm{C}$ and $-7^{\circ} \mathrm{C}$ dropped below the "like" level (Figure 18). In fact, the peaches stored at $-7^{\circ} \mathrm{C}$ dropped to 1 "extremely dislike" on the $1-15$ scale. There was no significant difference in peaches' sensory scores when stored at $-77^{\circ} \mathrm{C}$ and $-29^{\circ} \mathrm{C}$ on days $30,90,180,270$, and 360. Peaches stored at $-29^{\circ} \mathrm{C}$ were scored higher than those stored at $-12^{\circ} \mathrm{C}$ and $-7^{\circ} \mathrm{C}$ on days $30,90,180,270$, and 360 .
The quality attributes of peaches stored at $-7^{\circ} \mathrm{C}$ were significantly lower than other freezers in days 30, 90, 180, 270, and 360 .

\section{Conclusions}

Fast freezing at $-29^{\circ} \mathrm{C}$ and $-77^{\circ} \mathrm{C}$ generally maintained peach quality than slow freezing at other temperatures after freezing before thawing. However, all treatments displayed enzymatic browning after thawing. Once frozen, long-term frozen storage at $-29^{\circ} \mathrm{C}$ and $-77^{\circ} \mathrm{C}$ slowed the loss of nearly all quality attributes during the 12-month storage cycle compared to other storage temperatures. Interestingly, higher holding temperatures $\left(-12^{\circ} \mathrm{C}\right.$ and $\left.-18^{\circ} \mathrm{C}\right)$ were similar to lower temperatures $\left(-29^{\circ} \mathrm{C}\right.$ and $\left.-77^{\circ} \mathrm{C}\right)$ as far as sensory panel judgements through 90 days. Similar results were found for hexanal levels in that $-12^{\circ} \mathrm{C}$ and $-18^{\circ} \mathrm{C}$ showed minimal and similar hexanal levels as peaches stored at $-29^{\circ} \mathrm{C}$ and $-77^{\circ} \mathrm{C}$ through 90 days. Thus, peach quality can be maintained at these higher temperatures to potentially reduce energy costs while retaining quality during frozen storage.

\section{Data Availability}

The data for this research is available upon request.

\section{Conflicts of Interest}

The authors declare that they have no conflicts of interest. 


\section{Acknowledgments}

The Clemson University Experiment Station's technical contribution No.is 6849. This material is based upon work supported by NIFA/USDA, under project number SC-1700553 and SC-1700535.

\section{References}

[1] J. C. Rickman, D. M. Barrett, and C. M. Bruhn, "Nutritional comparison of fresh, frozen and canned fruits and vegetables. Part 1. Vitamins C and B and phenolic compounds," Journal of the Science of Food and Agriculture, vol. 87, no. 6, pp. 930944, 2007.

[2] D. S. Reid, "Fruit freezing," in Processing fruits: science and technology, L. P. Somogyi, H. S. Ramaswamy, and Y. H. Hui, Eds., vol. 1 of Biology, principles and applications, pp. 169184, Technomic Publishing Co, Lancaster, Pennsylvania, 2006.

[3] O. R. Fennema, Low temperature preservation of foods and living matter, O. R. Fennema, W. D. Powrie, and E. H. Marth, Eds., no. 3, 1973Plenum, New York, 1973.

[4] M. Siddiq, "Peach and nectarine," in Handbook of fruits and fruit processing, pp. 519-531, Blackwell Publishing, Ames, Iowa, USA, 2007.

[5] S. Chassagne-Berces, F. Fonseca, M. Citeau, and M. Marin, "Freezing protocol effect on quality properties of fruit tissue according to the fruit, the variety and the stage of maturity," LWT-Food Science and Technology, vol. 43, no. 9, pp. 14411449, 2010.

[6] N. N. Potter and J. H. Hotchkiss, "Cold preservation and processing," in Food science, D. R. Heldman, Ed., pp. 175-199, Chapman \& Hall, New York, 5th ed edition, 1986.

[7] R. C. Martins and C. L. M. Silva, "Modelling colour and chlorophyll losses of frozen green beans (Phaseolus vulgaris, L.)Haricots verts congelés : modélisation de la diminution de l'intensité de la couleur et de la teneur en chlorophylle," International Journal of Refrigeration, vol. 25, no. 7, pp. 966-974, 2002.

[8] F. R. Harker, R. J. Redgwell, I. C. Hallett, S. H. Murray, and G. Carter, "Texture of fresh fruit," in Horticultural Reviews: Janick/Horticultural Reviews, J. Janick, Ed., vol. 20, pp. 121224, John Wiley \& Sons, Inc, Oxford, UK, 2010.

[9] P. Garcia-Salas, A. Morales-Soto, A. Segura-Carretero, and A. Fernandez-Gutierrez, "Phenolic- compound-extraction systems for fruit and vegetable samples," Molecules, vol. 15, no. 12, pp. 8813-8826, 2010.

[10] M. A. Murcia and M. Martınez-Tome, "Antioxidant activity of resveratrol compared with common food additives," Journal of Food Protection, vol. 64, no. 3, pp. 379-384, 2001.

[11] C. A. Titchenal and J. Dobbs, "Nutritional value of vegetables," in Handbook of Vegetable Preservation and Processing, Y. H. Hui, S. Ghazala, D. M. Graham, K. D. Murrell, and W. Nip, Eds., pp. 23-37, Marcel Dekker, New York, NY, 2004.

[12] M. Ergun and K. M. Jezik, "Measuring electrochemical fruit quality of refrigerated 'Hanita' plum by Bioelectric Vincent method," Zemdirbyste-Agriculture, vol. 98, no. 3, pp. 315322, 2011.

[13] M. Remingon, The effect of freezing and refrigeration on food quality, vol. 2667, Clemson University, 2017, https:// tigerprints.clemson.edu/all_theses/2667.
[14] W. Brand-Williams, M. E. Cuvelier, and C. Berset, "Use of a free radical method to evaluate antioxidant activity," LWT Food Science and Technology, vol. 28, no. 1, pp. 25-30, 1995.

[15] P. Shinya, L. Contador, T. Frett, and R. Infante, "Effect of prolonged cold storage on the sensory quality of peach and nectarine," Postharvest Biology and Technology, vol. 95, pp. 7-12, 2014.

[16] G. V. Barbosa-Cánovas, B. Altunakar, and D. J. Mejía-Lorío, "Introduction to freezing," in Freezing of Fruits and Vegetables: An Agribusiness Alternative for Rural and Semi-Rural Areas, G. V. Barbosa-Cánovas, B. Altunakar, and D. J. Mejía-Lorío, Eds., vol. 1, pp. 1-36, Food and Agriculture Organization of the United Nations, Rome, 2005.

[17] D. R. Heldman and R. W. Hartel, "Freezing and Frozen-Food Storage," in Principles of Food Processing, D. R. Heldman, Ed., pp. 131-132, Aspen Publishers, Inc., Gaithersburg, MD, 1998.

[18] B. Woinet, J. Andrieu, M. Laurent, and S. G. Min, "Experimental and theoretical study of model food freezing. Part II. Characterization and modelling of the ice crystal size," Journal of Food Engineering, vol. 35, no. 4, pp. 395-407, 1998.

[19] G. Petzold and J. M. Aguilera, "Ice morphology: fundamentals and technological applications in foods," Food Biophysics, vol. 4, no. 4, pp. 378-396, 2009.

[20] K. S. Bahçeci, A. Serpen, V. Gökmen, and J. Acar, "Study of lipoxygenase and peroxidase as indicator enzymes in green beans: change of enzyme activity, ascorbic acid and chlorophylls during frozen storage," Journal of Food Engineering, vol. 66, no. 2, pp. 187-192, 2005.

[21] D. Chevalier, A. le Bail, and M. Ghoul, "Freezing and ice crystals formed in a cylindrical food model: part I. Freezing at atmospheric pressure," Journal of Food Engineering, vol. 46, no. 4, pp. 277-285, 2000.

[22] D. Sun, Handbook of Frozen Food Processing and Packaging, Taylor and Francis Group, New York, 2011.

[23] Y. H. Hui, N. K. Sinha, E. Ö. Evranuz, M. Siddıq, and J. Ahmed, Handbook of Vegetables \& Vegetable Processing, Wiley-Blackwell, 2011.

[24] B. . de Ancos, C. Sánchez-Moreno, S. de Pascual-Teresa, and M. P. Cano, "Freezing preservation of fruits," in Handbook of Fruits and Fruit Processing: Sinha/Handbook of Fruits and Fruit Processing, N. Sinha, J. S. Sidhu, J. Barta, J. S. B. Wu, and M. P. Cano, Eds., pp. 103-119, Wiley-Blackwell, Oxford, UK, 2nd ed edition, 2012.

[25] D. S. Reid, "Fruit freezing," in Processing Fruits-Science and Technology, L. Somogyi, H. S. Ramaswamy, and Y. H. Hui, Eds., pp. 169-183, CRC Press, Boca Raton, FL, 1996.

[26] M. Pilar Cano, C. Fuster, and M. Antonia Marin, "Freezing preservation of four Spanish kiwi fruit cultivars (Actinidia chinensis, Planch): chemical aspects," Zeitschrift fuer Lebensmittel-Untersuchung und -Forschung, vol. 196, no. 2, pp. 142-146, 1993.

[27] G. L. Robertson, "Changes in the chlorophyll and pheophytin concentrations of kiwifruit during processing and storage," Food Chemistry, vol. 17, no. 1, pp. 25-32, 1985.

[28] S. K. Lee and A. A. Kader, "Preharvest and postharvest factors influencing vitamin C content of horticultural crops," Postharvest Biology and Technology, vol. 20, no. 3, pp. 207-220, 2000.

[29] M. A. Sahari, F. Mohsen Boostani, and E. Zohreh Hamidi, "Effect of low temperature on the ascorbic acid content and quality characteristics of frozen strawberry," Food Chemistry, vol. 86, no. 3, pp. 357-363, 2004. 
[30] A. V. Rao, The Effect of Freezing and Freeze-Drying on the Physico-Chemical Changes in Northwest Strawberries [Phd Thesis], Oregon State University, 1967.

[31] T. Pukszta and P. Palich, "The effect of freezing conditions of strawberry storage on the level of thawing drip loss," Acta Agrophysica, vol. 9, no. 1, pp. 203-228, 2007.

[32] T. R. Gormley, "Freezing performance and quality of strawberries grown in peat and mineral soil," Irish journal of food science and technology, vol. 1, no. 1, pp. 33-41, 1977.

[33] G. Cortellino, "Quality and safety of frozen fruits," in Handbook of Frozen Food Processing and Packaging, D.-W. Sun, Ed., pp. 435-460, CRC Press, Boca Raton, FL, 2nd ed edition, 2012.

[34] M. S. Rahman, "Food preservation by freezing," in Handbook of Food Preservation, M. S. Rhaman, Ed., pp. 259-284, New York, Marcel Dekker, 1999.

[35] G. Bonat Celli, A. Ghanem, and M. Su-Ling Brooks, "Influence of freezing process and frozen storage on the quality of fruits and fruit products," Food Review International, vol. 32, no. 3, pp. 280-304, 2015.

[36] P. Allan-Wojtas, H. D. Goff, R. Stark, and S. Carbyn, “The effect of freezing method and frozen storage conditions on the microstructure of wild blueberries as observed by coldstage scanning electron microscopy," Scanning, vol. 21, no. 5, p. 347, 1999.

[37] P. T. Gardner, T. A. C. White, D. B. McPhail, and G. G. Duthie, "The relative contributions of vitamin $\mathrm{C}$, carotenoids and phenolics to the antioxidant potential of fruit juices," Food Chemistry, vol. 68, no. 4, pp. 471-474, 2000.

[38] B. de Ancos, E. M. González, and M. P. Cano, "Ellagic acid, vitamin $\mathrm{C}$ and total phenolic contents and radical scavenging capacity affected by freezing and frozen storage in raspberry fruit," Journal of Agricultural Food and Chemistry, vol. 48, no. 10, pp. 4565-4570, 2000.

[39] X. Y. Zhao, W. N. Zhang, X. R. Yin et al., "Phenolic composition and antioxidant properties of different peach [Prunus persica (L.) Batsch] cultivars in China," International Journal of Molecular Sciences, vol. 16, no. 12, pp. 5762-5778, 2015.

[40] G. Skrede, "Fruits," in Freezing Effects on Food Quality, E. J. Lester, Ed., pp. 183-245, Marcel Dekker Inc., New York, 1996.

[41] Z. Lisiewska and W. Kmiecik, "Effect of storage period and temperature on the chemical composition and organoleptic quality of frozen tomato cubes," Food Chemistry, vol. 70, no. 2, pp. 167-173, 2000. 